\title{
EL HECHO GENERADOR
} DEL INCUMPLIMIENTO CONTRACTUAL Y EL ARTÍCULO 1547 DEL CÓDIGO CIVIL

\section{THE EVENT GIVING RISE TO CONTRACT NON-PERFORMANCE AND SECTION 1547 OF THE CHILEAN CIVIL CODE}

\section{O FATO GERADOR DO INCUMPRIMENTO CONTRATUAL E O ARTIGO 1547 DO CÓDIGO CIVIL}

Sergio Urrejola Santa María*

\section{RESUMEN}

Interpretando únicamente los artículos de nuestro Código Civil y en especial su artículo 1547, la doctrina nacional señala que el hecho generador del incumplimiento contractual, uno de los elementos para establecer la responsabilidad en este ámbito, se configura tras constatar dos elementos: la existencia de la inejecución de la prestación debida y que esta misma sea consecuencia de una conducta culposa o dolosa por parte del deudor, siendo su culpa un elemento fundamental para establecerla. A través del presente trabajo intentaremos demostrar que la responsabilidad contractual establecida en el Código Civil puede configurarse sin el segundo de dichos elementos, es decir, sin culpa o sin dolo y que, por ende, el artículo 1547 del Código Civil tiene un campo de aplicación circunscrito sólo al incumplimiento de algunas obligaciones de hacer no teniendo un campo de aplicación general. Efecto de ello es que el Código Civil establece conjuntamente, según el tipo de obligación, un hecho generador basado en la culpa del deudor que conlleva a una responsabilidad contractual subjetiva y otro que prescinde del mencionado juicio de reproche para su configuración, lo que conlleva a una responsabilidad contractual objetiva.

*Abogado, Universidad Diego Portales. DSU Droit Civil, Universidad Panthéon-Assas (Paris 2). Dirección postal: Cerro El Plomo, No 2950, piso 19, Las Condes, Santiago, Chile. Artículo recibido el 1 de noviembre de 2010 y aceptado para su publicación el 23 de junio de 2011. Correo electrónico: surrejola@porzio.cl 
Palabras clave: hecho generador, culpa contractual, obligaciones de medios, obligaciones de resultados, artículo 1547 del Código Civil.

\section{AbStRACT}

By merely construing the sections in our Civil Code and, in particular, Section 1547 thereof, Chilean legal scholars point out that the event giving rise to contract non-performance, that is to say, one of the factors to establish contract liability, arises upon the presence of two elements: failure to fulfill an obligation due and the fact that such failure hails from fraudulent or negligent conduct on the part of the debtor, the debtor's negligence being an essential element of contract liability. Throughout this paper, we intend to show that contract liability as set forth in the Civil Code may arise in the absence of the second element, that is to say, without fraud or negligence on the part of the debtor, and that, therefore, the scope of application of Section 1547 of the Civil Code is limited to the failure to fulfill certain obligations to perform an act only, which means that it is not general in nature. As a result, depending on the type of obligation, the Civil Code provides for both an event giving rise to contract non-performance based on the debtor's negligence, leading to subjective contract liability, and another event which makes no value judgment on the debtor's conduct, leading to objective contract liability.

Keywords: event giving rise to contract non-performance, contract negligence, obligation of means, obligation of result, Section 1547 of the Civil Code.

\section{RESUMO}

Interpretando unicamente os artigos de nosso Código Civil e em especial seu artigo 1547, a doutrina nacional assinala que o fato gerador do incumprimento contratual, um dos elementos para estabelecer a responsabilidade contratual, se configura depois de constatar dois elementos: a existência da inexecução da prestação devida e que dita inexecução seja consequência de uma conduta culposa ou dolosa por parte do devedor, sendo a culpa do devedor um elemento fundamental da responsabilidade contratual. Através do presente trabalho tentaremos demonstrar que a responsabilidade contratual estabelecida no Código Civil pode se configurar sem o segundo de ditos elementos, quer dizer sem a culpa ou sem o dolo do devedor e que, por isso, o artigo 1547 do Código Civil tem un campo de aplicação circunscrito unicamente à inexecução de algumas obrigações, um fato gerador do incumprimento contratual baseado na culpa do devedor que acarreta a uma responsabilidade contratual subjetiva e outro 
que prescinde do julgamento de censura sobre a conduta do devedor para sua configuração, o que acarreta a uma responsabilidade contratual objetiva.

Palavras chave: fato gerador, culpa contratual, obrigações de meios, obrigações de resultados, artigo 1547 do Código Civil.

\section{INTRODUCCIÓN}

A través del presente estudio intentaremos demostrar que el artículo 1547 del $C C$ tiene un campo de aplicación limitado únicamente a la inejecución de ciertas obligaciones de hacer, careciendo de aplicación general. En paralelo, intentaremos demostrar que el $C C$ estableció tanto un hecho generador subjetivo del incumplimiento contractual (basado en la conducta reprochable o culpable del deudor), como un hecho generador objetivo (que prescinde de la calificación de dicha conducta) que impide al deudor acreditar el cumplimiento de su obligación por medio de la prueba de la debida diligencia.

Para demostrar lo anterior dividiremos nuestro trabajo en dos partes. En la primera de ellas nos centraremos en el hecho generador del incumplimiento de las obligaciones contractuales, constatando que para algunas de ellas se exige tanto la acreditación de la inejecución de la prestación debida como la acreditación de la conducta reprochable o culpable del deudor (sea a través de una presunción legal de culpa sea a través de su prueba) y que, para otras obligaciones sólo basta acreditar la infracción de lo prometido o de lo pactado para establecer el incumplimiento, prescindiendo de la calificación de la conducta del deudor en diligente o culpable. En la segunda parte, trataremos las consecuencias y efectos de un inejecución contractual objetiva, analizando sus efectos y descartando el argumento de que el artículo 1547 del $C C$ tiene un campo de aplicación general y que todo incumplimiento contractual es atribuible a la culpa del deudor.

\section{El HECHO GENERADOR DEL INCUMPLIMIENTO}

de la obligación contractual en el Código Civil chileno

Para que el deudor de una obligación contractual sea responsable de su incumplimiento es necesario la constatación de los siguientes elementos:

- un hecho generador por parte del deudor;

- la existencia de un daño sufrido por el acreedor;

- la existencia de un vínculo causal que una al hecho generador con el daño sufrido por el acreedor y

- la constitución en mora del deudor. 
En el presente trabajo sólo nos centraremos en el hecho generador del incumplimiento contractual.

Para analizar el elemento hecho generador, nos centraremos en las normas establecidas en el CC. Primero analizaremos el artículo 1547 y la necesidad de valorar la conducta del deudor, para, posteriormente, analizar diferentes obligaciones establecidas en el $C C$ que prescinden de la valoración de dicha conducta para configurar el incumplimiento contractual, bastando acreditar la inejecución de lo prometido o pactado. Consecuencia de esto último: el deudor se ve imposibilitado de probar el cumplimiento de su obligación a través de la prueba de su debida diligencia.

\section{El artículo 1547 del Código Civil y la culpa como fundamento del incumplimiento de la obligación contractual}

La obligación contractual nace tras el acuerdo de voluntades que forman el contrato, donde, por una parte, está el derecho del acreedor y, por otra, está el deber del deudor, siendo el objeto del acuerdo la prestación debida. Tradicionalmente, se define obligación como el vínculo jurídico existente entre personas determinadas, en virtud de la cual una de ellas, el deudor, se encuentra en la necesidad de dar, hacer o no hacer alguna cosa, respecto de la otra, el acreedor. Lo normal es que se cumpla con lo pactado, pero, ¿̇qué ocurre cuando no se cumple con ello? El $C C$ no nos entrega una definición de incumplimiento contractual, sin embargo, establece en su artículo 1556 los efectos que produce dicha inejecución, cual es la indemnización de los perjuicios. Según dicho artículo, la indemnización de los perjuicios se debe en tres hipótesis:

- cuando no se cumplió con la obligación;

- cuando se cumplió imperfectamente y

- cuando hubo cumplimiento, pero fuera del período estipulado. Asimismo, para que la indemnización proceda es necesario constatar todos los elementos del incumplimiento de la obligación por parte del acreedor. En el presente trabajo nos centraremos en el primero de dichos elementos, a saber, el hecho generador del incumplimiento contractual.

La gran mayoría de la doctrina nacional considera que para configurar el hecho generador del incumplimiento de la obligación se debe acreditar, sobre la base de lo dispuesto en el artículo 1547 del $C C$, tanto la infracción de la prestación debida como la culpa o el dolo del deudor ${ }^{1}$. Se argumenta

${ }^{1}$ José Clemente Fabres, Instituciones de derecho civil chileno, $2^{\mathrm{a}}$ ed., Santiago, Ercilla, 1902, tomo it, No 178, p. 105; Alfredo Barros Errázuriz, Curso de derecho civil. Segundo año, primera parte, $4^{\mathrm{a}}$ ed., Santiago, Nascimento, 1932, vol. 2, No 44, pp. 74-75; Luis Claro Solar, Explicaciones Derecho Civil chileno y Comparado, Santiago, Nascimento, 1937, tomo 
que no hay responsabilidad sin culpabilidad ${ }^{2}$ y que no es posible poner en duda que la culpa es el elemento esencial de la responsabilidad contractual en el sistema de nuestro $C C^{3}$. Por el contrario, las opiniones que argumentan que la culpa no sería un elemento necesario para configurar dicho régimen de responsabilidad son excepcionales ${ }^{4}$.

\section{a) La culpa contractual}

Una conducta reprochable o culpable consiste en haber actuado con culpa o con dolo, entendiendo por la primera, la falta de aquel cuidado o diligencia que debe emplearse en el cumplimiento de una obligación contractual, sin intensión de dañar y, por la segunda, los actos u omisiones realizados intencionalmente con la finalidad de no cumplir lo pactado ${ }^{5}$ (en adelante sólo nos referiremos a la culpa contractual omitiendo voluntariamente al dolo). Inherente a la idea de culpa se encuentra la noción de diligencia, conceptos que se contraponen uno del otro, siendo la valoración de la conducta del deudor la herramienta para determinar si este actuó en forma diligente o con culpa en la ejecución de la prestación debida. La valoración

XI, No 1048, p. 499; Arturo Alessandri, De las obligaciones, Santiago, Nascimento, 1941, p. 177; Sergio Gatica Pacheco, Aspectos de la indemnización de perjuicios por incumplimiento del contrato, Santiago, Editorial Jurídica de Chile, 1959, No 46, p. 63 y No 54, p. 75; Fernando FuEYo L., Cumplimiento e incumplimiento de las obligaciones, $3^{\mathrm{a}}$ ed., Santiago, Editorial Jurídica de Chile, 2004, pp. 392 y 420; René Abeliuk M., Las obligaciones, Santiago, Editorial Jurídica de Chile, 2008, tomo II, No 821, p. 673 y No 792, p. 653; Lorenzo DE LA MAZA R., "Responsabilidad contractual", en Revista Chilena de Derecho, vol. 16, Santiago, 1989, p. 620 y ss.; Pablo Rodríguez G., Responsabilidad contractual, Santiago, Editorial Jurídica de Chile, 2003, p. 142 y ss; Víctor Vial Del Río, Manual del Derecho de las Obligaciones en el Código Civil chileno, Santiago, Editorial Biblioteca Americana, 2003, No 80, p. 210.

${ }^{2}$ Fueyo (n. 1), pp. 420, 392-393.

${ }^{3}$ Ramón Domínguez Águila, "La culpa en el derecho civil chileno. Aspectos generales", en Revista Anales Derecho UC. Temas de Responsabilidad Civil, No 3, Santiago, 2008, p.108 y ss.

${ }^{4}$ Véase Jorge Baraona GonZÁlez, "Responsabilidad contractual y factores de imputabilidad de daños: apuntes para una relectura en clave objetiva", en Revista Chilena de Derecho, vol. 24, No 1, Santiago, 1997, p. 152, quien argumenta: "la solución culpabilística está lejos de ser una doctrina que emane con fluidez de nuestro principal Cuerpo Civil, al menos en todos los extremos que hasta ahora se ha pretendido". Con similar conclusión, pero desde otro ángulo, véase el trabajo de Daniel Peñallillo Arévalo, "Responsabilidad contractual objetiva", en Carlos Pizarro (coord.), Estudios de Derecho Civil IV, Santiago, Legal Publishing, 2009, p. 331-346. Por último, véase el trabajo de Alejandro García GonZÁlez, Responsabilidad civil contractual-obligaciones de medios y de resultado, Santiago, LexisNexis, 2002.

${ }^{5}$ Hernán Larraín R., Teoría general de las obligaciones, Santiago, LexisNexis, 2002, pp. 238 y 242. Asimismo, Arturo Alessandri R., Manuel Somarriva U. y Antonio Vodanovic H., Tratado de las obligaciones. Del cumplimiento e incumplimiento de las obligaciones, $2^{\mathrm{a}}$ ed., Santiago, Editorial Jurídica de Chile, 2004, No 837, p. 270. 
de su conducta se determina a través del denominado juicio de reproche, que es un juicio de valor sobre su actuación, que tiene por finalidad determinar o establecer si se comportó o no como un hombre medio, como un buen padre de familia en la ejecución de la prestación ${ }^{6}$.

La valoración de la conducta del deudor la encontramos desde el Derecho Romano a través del concepto de bonus paterfamilias ${ }^{7}$ bajo un criterio objetivo $^{8}$ que prescindió de un juicio concreto a la actuación del mismo, ya que la culpa no procedía del interior del sujeto ${ }^{9}$. Con el transcurso de los siglos, la valoración de la conducta del deudor se fue subjetivando producto de la fuerte influencia del Derecho Natural y de la moral ${ }^{10}$ remarcándose dicha corriente en los siglos XVII, XVIII y XIX a través de lo que algunos han denominado las "pautas moralistas con base en la idea de culpa"11 fuertemente influenciado por "el sencillo principio de derecho natural, que quiere que se haga por los demás lo que querríamos que ellos hicieran por

${ }^{6}$ Para acreditar la culpa del deudor tanto la jurisprudencia como la doctrina están de acuerdo en que el criterio para realizar la valoración es abstracto. Por el contrario, en caso de dolo, es necesario un criterio que valore la conducta del deudor mismo, una valoración en concreto.

$32 \quad{ }^{7}$ Una evolución histórica de dicho concepto en la primera parte del trabajo de Gian Franco Rosso Elorriaga, "El buen padre de familia como criterio de apreciación de la culpa y su aplicación a la responsabilidad civil cuasidelictual”, en VV.AA., Derecho de Daños, Santiago, Lexisnexis, 2002, pp. 3-24. Se debe tener presente que en el Derecho Romano la noción de culpa como fundamento general de la responsabilidad no era aún conocida, así, por ejemplo, Mireille BACACHE-GIBEILI, Les obligations. La responsabilité civile extracontractuelle, sous la direction de Christian Larroumet, Paris, Economica, 2007, tome $\mathrm{v}, \mathrm{N}^{\mathrm{O}} 106$, p. 118

${ }^{8}$ Rosso Elorriaga (n. 7), pp. 3-24.

${ }^{9}$ Betty Mercedes Martínez Cárdenas, "La faute y la culpa”, en Fabricio Mantilla Espinosa y Carlos Pizarro Wilson (coords.), Estudios de Derecho Privado en homenaje a Christian Larroumet, Santiago-Bogotá, Ediciones de la Fundación Fernando Fueyo, Universidad Diego Portales-Universidad del Rosario, 2008, p. 275.

${ }^{10}$ Georges Ripert, La régle morale dans les obligations civiles, $2^{\text {ème }}$ ed., Paris, LGDJ, $1927, N^{\circ} 112$, p. 205, señala: "il est certain que les canonistes, par leurs subtiles analyses des passions humaines, ont aidé à peser la fardeau de la responsabilité. Au momento où le Code civil est rédigé, la règle général est acquise". También Geneviève VInEY, Traité de Droit Civil, Introduction à la Responsabilité, $2^{\text {ème }}$ ed., Paris, LGDJ, 1995, No 11-12, p. 11 y ss. En igual sentido Martínez Cárdenas (n. 9), p. 278, asevera: “debido a la fuerte intervención de la Iglesia en la valoración subjetiva de la misma a través de la idea del pecado y se desarrollara la noción de faute en el contrato como incumplimiento de la palabra dada". Por otra parte, se ha establecido que la evolución de la responsabilidad civil sólo será justa si es inspirada por la ética, llamada por otros moral. Jürgen HABERMAS, Derecho y moral, 1996, en Yvonne Lambert-Faivre, "L'éthique de la responsabilité", dans RTD Civil, Paris, 1998, p. 22.

${ }^{11}$ Rodríguez Grez (n. 1), No 515, p. 321 
nosotros" 12 , estableciendo en la culpa, configurada a través de un juicio de reproche, un elemento fundamental para la procedencia del incumplimiento contractual. Lo anterior trajo como consecuencia que de dicho juicio de reproche decantara el principio de que la responsabilidad civil se funda en la idea de una conducta reprochable del deudor, a causa de una falta de éste $^{13}$. El trasfondo de la idea de culpa y su juicio de reproche era reconocer que el deudor tiene la capacidad de discernir las consecuencias de sus actos, estableciéndose el principio según el cual éste debe cumplir con sus obligaciones a través de un comportamiento diligente. Ello significó que después del Ancien Droit y antes de la codificación, el principio de responsabilidad civil fundado en la idea de la culpa, configurada a través de un juicio de reproche, constituía un principio irrefutable ${ }^{14}$. En otras palabras, antes de la codificación civil francesa de 1804 estaba ya bastante decantada la idea de que, para que el deudor sea responsable de la inejecución de su prestación contractual, no bastaba con probar o acreditar en los hechos el incumplimiento de lo prometido, también era necesario probar o acreditar que la conducta no fue diligente, es decir, que actuó con culpa y que producto de ello no se ejecutó la prestación debida ${ }^{15}$. Así se concretó la idea de que el deudor cumplía con su obligación contractual si acreditaba que se comportó con diligencia en su ejecución, sea ésta de dar, de hacer o de no hacer algo, a pesar de que tras desplegar dicha conducta no haya dado, hecho o no hecho la prestación debida ${ }^{16}$.

El principio consistente en que la culpa era el fundamento de la responsabilidad civil fue recepcionado en los artículos 1136 y 1137 del Código Civil francés ${ }^{17}$, los cuales establecen que es necesario, por parte del

${ }^{12}$ Henri y Léon Mazeaud y André Tunc, Tratado teórico y práctico de la responsabilidad civil delictual y contractual, Buenos Aires, Ediciones Jurídica Europa-América, 1961, tomo 1, vol. 1, No 52, pp. 70-71, quienes sobre la base de dicha máxima explican el espíritu con el cual fue redactado el artículo 1137 del Código Civil francés y la noción de "buen padre de familia". En igual sentido, Philippe Rémy , "La responsabilité contractuelle: histoire d'un faux concept", dans RTD Civil, Paris, 1997, No 8, p. 323 et ss. y Paul COËFFARD, Garantie des vices cachés et "responsabilité contractuelle de droit commun", préface de Philippe Rémy, Paris, LGDJ, 2005, N ${ }^{\circ} 156$, p. 111, quien citando a Charles B.M. Toullier manifiesta que la fuerte influencia de santo Tomás en el Derecho con la máxima "no hacer ha otro lo que no quieres que te hagan", Charles Bonaventure Marie TOULLIER, Le droit civil français suivant l'ordre du Code, $4^{\text {ème }}$ ed., Paris, B. Warée, 1824, tome vi, No 231, 232 et 215.

${ }^{13}$ Bacache-Gibeili (n. 7), No 106, p. 118.

${ }^{14}$ Viney (n. 10), No 12, p. 16.

${ }^{15}$ Christian Larroumet, Les Obligations. Le Contrat, Effets, $6^{\text {ème }}$ ed., Paris, Economica, 2007, tome III, $2^{\text {ème }}$ partie, $\mathrm{N}^{\mathrm{O}} 605$, p. 635

${ }^{16}$ Mazeaud et Tunc (n. 12), No 53, pp. 72-73.

${ }^{17} \mathrm{El}$ artículo 1136 del Código Civil francés dispone: "L'obligation de donner emporte celle de livrer la chose et de la conserver jusqu'à la livraison, à peine de dommages et intérêts envers le créancier". Por su parte, el inciso primero del artículo 1137 dispone: 
deudor, desplegar una conducta tipo -la de un buen padre de familiapara cumplir con la obligación contractual de cuidado respecto a la cosa debida. Ello significó que para que hubiese responsabilidad por parte del deudor fuera necesario acreditar la no diligencia de éste, siendo suficiente constatar una culpa cualquiera ${ }^{18}$.

Dichos artículos recogen las ideas que Robert J. Pothier estableció para el cuidado de la cosa que se debe, quien en el siglo XviII ya señalaba que cuando el deudor le debe al acreedor un cuerpo cierto se obliga a desplegar los cuidados necesarios para la conservación de la cosa debida hasta su entrega. Si en el evento de no desplegar dichos cuidados la cosa debida se deterioraba, se destruía o se perdía, el deudor debía pagar los perjuicios que dicho deterioro, destrucción o pérdida le ocasionaban al acreedor. El fundamento de tal responsabilidad es el no haber dado a la cosa los cuidados necesarios, es decir, haber actuado con una conducta negligente o con culpa ${ }^{19}$. Lo relevante de las ideas desarrolladas en dicha época y enseñadas por Robert J. Pothier ${ }^{20}$ era que el deudor sólo sería responsable del deterioro, de la pérdida o de la destrucción de la cosa debida si no hubiese desplegado una conducta diligente en el cuidado y conservación de ella. Por el contrario, si desplegaba una conducta diligente e igualmente ésta sufría un deterioro, un daño o se perdía, el deudor no sería responsable frente al acreedor porque se había comportado en forma diligente.

El mecanismo descrito influyó en la redacción de nuestro $C C$, estableciendo Andrés Bello en el artículo 44 la definición de las tres clases de culpa utilizada por Robert J. Pothier a propósito del cuidado de las $\operatorname{cosas}^{21}$

"L'obligation de veiller à la conservation de la chose, soit que la convention n'ait pour objet que l'utilité de l'une des parties, sois qu'elle ait pour objet leur utilité commune, soumet celui qui en est chargé à y apporter tous les soins d'un bon père de famille", y su inciso segundo: "Cette obligations est plus ou moins étendue relativement à certains contrats, dont les effets, à cet égard, sont expliqués sous les titres qui les concernent”.

${ }^{18}$ Mazeaud et Tunc (n. 12), N $\mathrm{N}^{\mathrm{O}}$ 53, p. 71.

${ }^{19}$ Robert-Joseph Pothier, Euvres de Pothier, Traité des obligations, $3{ }^{\text {ème }}$ par M.Jean-Joseph Bugnet, Paris, Imprimerie L. Baudoin, 1890, tome 2, No 142, p. 66. Siendo su primera edición publicada en 1761.

${ }^{20}$ Cabe señalar que, como veremos más adelante en especial la nota al pie 58 de este trabajo, en la obra de Robert J. Pothier la culpa o faute se encuentra circunscrita a las obligaciones que tienen por finalidad el cuidado de cosas ajenas. En igual sentido véase el trabajo de Rosso ElorRiaga (n. 7), quien se refiere a la culpa en Robert Pothier, pp. 21-22 y 24, y a la culpa en Jean Domat, pp. 20-21. Asimismo, Denis Tallon, "Pourquoi parler de faute contractuelle?", dans Jean Beauchard et Pierre Couvrat, Droit Civil, procédure, linguistique juridique. Écrits en hommage à Gerard Cornu, Paris, PUF, 1994, p. 429 et ss., tras analizar, entre otros, los trabajos de Robert J. Pothier y Jean Domat concluye que no tiene sentido hablar de la culpa contractual.

${ }^{21}$ Robert Joseph Pothier, "De la prestation des Fautes", dans Robert-Joseph Pothier, Euvres de Pothier, Traité des obligations, $3^{\text {ème }}$ par M. Jean-Joseph Bugnet, Paris, Imprimerie L. 
y estableciendo el campo de aplicación en el inciso $1^{\circ}$ del artículo 1547 , enmarcado este último dentro del título xII del libro IV del $C C$ denominado "Del efecto de las obligaciones".

Como consecuencia de todo lo descrito, es decir, de la definición de las tres clases de culpa establecidas en nuestro $C C$, de la ubicación del artículo 1547 , sumando el criterio imperante respecto del juicio de reproche ya señalado, la doctrina nacional le concedió al inciso $1^{\circ}$ del artículo 1547 y sus tres grados de culpa un campo de aplicación general ${ }^{22}$, susceptible de ser implementado en todos los contratos y a todas sus obligaciones, indicándose:

"al artículo 1547 se refiere a los contratos, sin distinguir la naturaleza de las obligaciones que de ellos nacen, sean obligaciones de dar o de hacer o de no hacer; de modo que se aplica a todas ellas" ${ }^{23}$,

constituyendo dicho artículo la norma general en materia de responsabilidad contractual ${ }^{24}$. Efecto de lo anterior, se concluyó.

"nuestro Código reconoce un sistema de responsabilidad subjetiva, esto es, basado en la conducta culposa o dolosa del sujeto o agente. Esto se observa tanto en la responsabilidad extracontractual como en la contractual" 25 ,

Baudoin, 1890, tome 2, p. 497. Cabe señalar que la clasificación tripartita de culpa, esto es, en culpa grave, culpa leve y culpa levísima fue desechada por los redactores del Código Civilfrancés de 1804 bajo el argumento de que era mas ingeniosa que útil y que, en realidad, el juez, al efectuar el juicio de valor sobre la conducta del deudor establecería diferentes grados de diligencia según cada contrato y cada obligación. Un ensayo en contra de la clasificación tripartita en Dennis LE BRUn, "Essai sur la prestation des fautes, ou l'on examine combien les lois romaines en distinguent d'espèces", publicado en Paris por Saugrain en 1764 y anexado en Robert-Joseph Pothier, Euvres de Pothier, Traité des obligations, ${ }^{3 \mathrm{èm}}$ par $M$. Jean-Joseph Bugnet, Paris, Imprimerie L. Baudoin, 1890, tome 2, pp. 503-526.

${ }_{22}$ Artículo que para la doctrina nacional es de aplicación general, pero no imperativo. Véase a Alessandri, Somarriva y Vodanovic (n. 5), No 843, p. 276, quienes señalan: "Las reglas sobre la culpa de que se responde según las diversas clases de contrato también pueden ser alteradas por la estipulación expresa de las partes". En igual sentido AbELIUK M. (n. 1), No 834, pp. 823-824; FueYo L. (n. 1), p. 428 y LARRAín R. (n. 5), p. 248.

${ }^{23}$ Claro Solar (n. 1), No 1067, p. 521. En igual sentido, véase Álvaro Vidal Olivares, "Incumplimiento y atribución de responsabilidad en las obligaciones de medio y resultado (a propósito de una sentencia de la Corte Suprema No ingreso 1.771-2008)", en FACUlTAD DE Derecho, Universidad de Concepción, Estudios de Derecho Civil V, Santiago, AbeledoPerrot, 2010, p. 582 quien sostiene: "Nuestra responsabilidad civil por incumplimiento se apoya en el criterio de atribución de responsabilidad de la culpa, cualquiera sea la obligación incumplida y prevé como causa de exoneración única el caso fortuito que obsta tal responsabilidad".

${ }^{24}$ Larraín R. (n. 5), p. 248. En igual sentido, Vial del Río (n. 1), No 83, p. 217.

${ }^{25}$ Fueyo Laneri (n. 1), p. 393. 
que se traduce en que la culpa es el fundamento de la responsabilidad contractual ${ }^{26}$.

\section{b) La presunción de la culpa contractual}

Para la doctrina nacional, Andrés Bello no sólo estableció en el artículo 1547 del $C C$ un sistema de responsabilidad subjetiva sino que, también, distribuyó la carga procesal de la prueba al presumir la culpa del deudor.

$\mathrm{Al}$ establecer en el inciso $3^{\circ}$ del artículo 1547 del $C C$ que la prueba de la debida diligencia recaía en quien debió emplearla, distribuyó la carga procesal de la acreditación de los dos elementos del hecho generador del incumplimiento contractual, lo que significó una innovación respecto a las ideas expresadas por Robert J. Pothier y por los redactores del Código Civil francés. Por una parte, Andrés Bello exigió al acreedor que probará la existencia de la obligación debida, según lo dispuesto en el artículo 1698 del $C C$ y, por la otra, según dispone el mismo artículo, estableció que la prueba del cumplimiento recaía sobre el deudor, a quien, además, se le presume culpable por lo dispuesto en el inciso $3^{\circ}$ del artículo 1547 del $C C$. Consecuencia de ello: tras la prueba de la existencia de la obligación por parte del acreedor, el deudor debe probar que cumplió con la prestación contractual o, en su defecto, que actuó con diligencia, es decir, sin culpa, según lo dispuesto en el artículo 1698 y en el inciso $3^{\circ}$ del artículo 1547, respectivamente.

Esta distribución significó una diferencia importante a la manera en el cómo se distribuían las cargas probatorias en el siglo XIX y, en especial, la prueba del hecho generador del incumplimiento contractual en el Código Civil francés, el que imponía al acreedor no sólo la prueba de la existencia de la obligación sino que, además, la prueba de su inejecución y de la culpa o falta de diligencia del deudor ${ }^{27}$.

${ }^{26}$ Domínguez Águila (n. 3), p. 108.

${ }^{27}$ Andrés Bello, al distribuir la carga de la prueba de los diferentes elementos del hecho generador del incumplimiento contractual evitó que en Chile tuviera desarrollo el principio de las cargas dinámicas de la prueba, principio que pretende distribuir caso a caso la carga de la prueba de todos los elementos del hecho generador. Dicho principio postula que las reglas de distribución de las cargas se deben definir dependiendo de las circunstancias concretas del caso, debiendo cargar con la prueba de lo discutido la parte que se encuentra en mejores condiciones para producir dicha la prueba, independientemente de si es demandante o demandado.

El principio de las cargas dinámicas de la prueba ha sido recogido en el proyecto de ley sobre el nuevo Código Procesal Civil chileno, enviado a la Cámara de Diputados en el mes de mayo de 2009, en la primera parte del inciso $2^{\circ}$ del artículo 264 de dicho proyecto de Código, al disponer: "El tribunal podrá distribuir la carga de la prueba conforme a la disponibilidad y facilidad probatoria que posea cada una de las partes en el litigio...”. 
c) Consecuencia de los incisos $1^{\circ}$ y $3^{\circ}$ del artículo 1547

y del artículo 1698, ambos del Código Civil,

en la prueba del hecho generador

Tras lo expuesto tenemos que al inciso $1^{\circ}$ del artículo 1547 del $C C$, la doctrina le ha concedido un campo de aplicación general en materia de cumplimiento de la obligación contractual, que se traduce en que el deudor debe emplear en la ejecución de su prestación el grado de diligencia que le exige el artículo 1547 en relación con el artículo 44, ambos del $C C$. Efecto de ello: el deudor únicamente se obliga a desplegar en la ejecución de la prestación debida una determinada conducta basada en la diligencia y en el cuidado, pudiendo siempre acreditar que cumplió con la obligación contractual probando que empleó toda la diligencia o procuró todo el cuidado al que estaba obligado, independientemente que la prestación debida no ejecutada haya sido una obligación de dar, de hacer o de no hacer ${ }^{28}$.

En paralelo, el inciso $3^{\circ}$ del artículo 1547 del $C C$ presumió la culpa del deudor. Presumió que la conducta fue negligente en la inejecución de la prestación debida una vez que el acreedor acredita la existencia de la obligación contractual ${ }^{29}$. Pero al ser una presunción legal de culpa el mismo artículo permite al deudor desvirtuarla, acreditando que empleó la diligencia o cuidado a que estaba obligado y, por ende, acreditar que sí cumplión ${ }^{30}$. Así, el demandado deja sin efecto la pretensión de indemnización de perjuicios por parte del acreedor al no existir una conducta reprochable de su parte.

En otras palabras, la mecánica establecida en los incisos $1^{\circ}$ y $3^{\circ}$ el artículo 1547 y el artículo 1698, ambos del $C C$ permiten siempre al deudor

${ }^{28}$ Rodríguez Grez (n. 1), No 522.8, p. 329 indica: "De aquí que siempre el deudor pueda excepcionarse probando que ha empleado la diligencia y cuidado debidos". En igual sentido, De la Maza R. (n. 1), p. 621, argumenta que en la responsabilidad contractual a diferencia de la responsabilidad delictual, "el deudor puede exonerase de responsabilidad probando que empleó la debida diligencia, es decir, que no incurrió en un descuido o negligencia suficiente para hacerlo responsable".

${ }^{29}$ Alessandri R., Somarriva U. y Vodanovic (n. 5), sostienen: "todo incumplimiento de una obligación, cualquiera sea su clase, ha de presumirse culpable al deudor”, $N^{\circ}$ 846, p. 278. En igual sentido véase, por ejemplo, entre otros, el artículo 1671 que presume la culpa del deudor. Ahora bien, la regla del inciso $3^{\circ}$ del artículo 1547 no es una regla absoluta, ya que el mismo $C C$ establece situaciones donde el acreedor debe probar la culpa del deudor, como lo dispone el inciso final del artículo 2158 en relación con el artículo 2118, ambos del $C C$, Abeliuk M. (n. 1), No 836, p. 826.

${ }^{30}$ Claro Solar (n. 1), No 1070 , pp. 527-528 y N ${ }^{\circ} 1068$, pp. 524-525, señala que el deudor: "al ser demandado por el acreedor podrá defenderse invocando la imposibilidad en que se ha encontrado de cumplir la obligación, a pesar de la diligencia que él ha empleado, en los términos en que estaba obligado a prestarla", También en Rodríguez Grez (n. 1), No 522.8, p. 329. 
probar que cumplió con la obligación contractual a pesar de no haber podido ejecutar la prestación debida. Así lo ha resuelto la Excma. Corte Suprema, al afirmar:

"le corresponde al acreedor la prueba de la existencia de la obligación, siendo al deudor, en este caso la demandada, probar su cumplimiento, o en subsidio, su diligencia o finalmente, el caso fortuito, si se consideran de manera literal las normas de los artículos 1547 y 1698 del CC"31.

\section{d) El nexo causal de la responsabilidad contractual y el inciso $2^{\circ}$ del artículo 1547 del Código Civil}

Por último, con la redacción el artículo 1547 del $C C$, Andrés Bello también trató el nexo causal como elemento del incumplimiento contractual, estableciendo que si dicho elemento es destruido no se configurará la responsabilidad en este ámbito. La destrucción del nexo causal tiene que ser imputable a un hecho o acto ajeno al deudor, como lo es el caso fortuito, la fuerza mayor o el hecho de un tercero, siendo su efecto la configuración de un eximente de responsabilidad civil.

Ahora bien, y sin poner en duda el mecanismo establecido en los inciso $1^{\mathrm{o}}$ y $3^{\mathrm{o}}$ del artículo 1547 del $C C^{32}$, intentaremos demostrar que su campo

${ }^{31}$ Corte Suprema, casación en la forma y fondo de 10 de diciembre de 2008, rol 1771-07, No Microjuris MJJ19078, en especial el considerando $23^{\circ}$.

${ }^{32}$ En el Derecho colombiano, donde el artículo 1604 del $C C$ de dicho país es una copia exacta del artículo 1547 del $C C$ chileno, se ha criticado fuertemente el mecanismo establecido en dicho artículo, sosteniéndose que la graduación de culpas no puede tener una interpretación de aplicación general. Dicha línea argumentativa es liderada por Javier Tamayo Jaramillo, quien sostiene que el artículo 1604 del $C C$ colombiano no puede tener un campo de aplicación general. Así, afirma: "bien miradas las cosas, esa graduación de la culpa es inaplicable como principio general, ya que son tantas las contradicciones que encierra ese artículo 1604, que es imposible acomodarlo dentro de un contexto de interpretación general, dadas las numerosísimas excepciones en que no es ni aplicado ni aplicable, no solo por disposición expresa de la ley sino que por la naturaleza de las cosas", Javier Tamayo Jaramillo, Tratado de responsabilidad civil, $2^{\text {a }}$ reimpresión de la $2^{\text {a }}$ ed., Bogotá, Legis, 2008, $N^{\circ} 357$, p. 438. Los argumentos que da el profesor Javier Tamayo son variados, entre los que destacan los siguientes: 1. Que el artículo 1604 confunde contrato y obligación; 2. Que dicho artículo considera compatible la culpa y el caso fortuito; 3. Que dicho artículo no se aplica cuando la ley solo habla de culpa sin cualificarla; 4. Que la culpa presunta es incompatible con la graduación de culpa. $\mathrm{N}^{\mathrm{O}} 318$ a $\mathrm{N}^{\circ} 453$, en especial, véase $\mathrm{N}^{\circ} 357$ a 364 (véase, también, Javier TAmayo Jaramillo, La culpa contractual, Bogotá, Temis, 1990).

Sin perjuicio de lo anterior, a través del presente estudio, a pesar de compartir la misma conclusión (la no aplicación general del artículo 1547), los argumentos para fundar nuestra postura serán diferentes a las del tratadista colombiano. 
de aplicación carece de generalidad, encontrándose circunscrito sólo a la inejecución de determinadas obligaciones contractuales. Intentaremos demostrar que el mismo $C C$, en variadas hipótesis, no exige un juicio de reproche sobre la conducta desplegada por el deudor para configurar el hecho generador del incumplimiento, lo que impide a éste acreditar que cumplió con su obligación probando su debida diligencia.

\section{La exclusión de la prueba de la debida diligencia para acreditar el cumplimiento de la obligación contractual}

Tras el análisis del artículo 1547 del $C C$ hemos podido constatar que la doctrina nacional afirma que el deudor siempre podrá probar que cumplió con su obligación acreditado que actuó diligentemente.

A pesar de lo anterior, a continuación analizaremos diferentes obligaciones contractuales establecidas en nuestro $C C$, donde al deudor, tras la constatación de la no ejecución de lo prometido, no le es permitido probar el cumplimiento, acreditando que ha actuado de manera diligente. En dichos casos el hecho generador del incumplimiento se configura prescindiendo de la valoración de la conducta desplegada. En otras palabras, se prescinde de la culpa contractual para la configuración del incumplimiento.

a) La obligación de dar y su incumplimiento contractual

La obligación de dar tiene por objetivo transferir el dominio o constituir un derecho real, teniendo su fuente en los contratos que por su naturaleza sirven para transferir el dominio. Ésta puede recaer sobre una cosa de género determinado o sobre una especie o cuerpo cierto.

a.1) Obligaciones de dar una cosa de género determinado y su incumplimiento contractual

La obligación de dar una cosa de género determinado se cumple dando cualquier individuo del género que tenga una calidad a lo menos mediana $^{33}$, según lo disponen el artículo 1509 y siguientes del $C C$. Transfiriendo el dominio de la cosa o individuo con las características debidas se cumple con la obligación contractual. En caso de no dar la cosa de género debida resulta relevante determinar si el deudor puede probar su debida diligencia para acreditar el cumplimiento. Así, la pregunta es la siguiente: ¿puede el deudor de una obligación de dar una cosa de género

${ }^{33}$ Lo anterior, teniendo presente que las partes puedan determinar la calidad del individuo que se debe, donde el deudor cumplirá con su obligación ya no entregando un individuo de calidad mediana, sino que de la calidad establecida específicamente. 
acreditar el cumplimiento por medio de la prueba de su debida diligencia sin haberla dado?

Para responder lo anterior es necesario recurrir al artículo 1510 del $C C$, que recoge el principio genera non pereunt, una de las máximas del Derecho de Obligaciones. Dicho principio del Derecho se traduce en que la obligación del deudor subsistirá mientras exista en el comercio un individuo del género debido. Que el género no perezca significa que mientras exista en el comercio un individuo del género, la obligación del deudor de dar subsiste independiente de la conducta desplegada por él. Efecto de ello es que las causales generales de exoneración de responsabilidad (el hecho de un tercero, el caso fortuito o la fuerza mayor) no son aplicables como medios de defensa en caso de no ejecución de la prestación debida. Esto, porque independiente de dichas causales, continuará siendo posible transferir el dominio del individuo debido mientras sea posible encontrarlo en el comercio. Así, sólo es posible eximirse de la obligación contractual de dar una cosa de género, acreditando que no existen en el comercio un individuo con las características de la cosa prometida, independientemente de la diligencia desplegada por el deudor en la búsqueda de la cosa. A modo de ejemplo, podemos señalar que si el deudor pierde o se le destruye la cosa que se encuentra en su poder con la intención de darla a su acreedor y dicha pérdida o destrucción es causada por un hecho ajeno a él mismo, la obligación de dar subsistirá, no pudiendo defenderse con éxito argumentando que su pérdida o destrucción se debió a una hipótesis de caso fortuito, de fuerza mayor o de un hecho de un tercero. Asimismo, si el deudor está frente a una obligación de tracto sucesivo o de ejecución diferida, ellas subsistirán a pesar que, tras el transcurso del tiempo, la cosa de género debida haya aumentado en forma significativa su valor o que, en la ejecución de la obligación pactada sucesivamente aparezcan nuevos gastos que lleven consigo un exceso de onerosidad ${ }^{34}$, perdiendo la obligación, en ambos casos, su carácter conmutativo. Para dichas hipótesis, la doctrina ha descartado la actuación diligente del deudor como medio para acreditar el cumplimiento y ha centrado sus esfuerzos, sin éxito jurisprudencial y escaso apoyo doctrinal, en la denominada teoría de la imprevisión ${ }^{35}$. Dicha teoría hace sus esfuerzos en que un tercero,

${ }^{34}$ Corte Suprema, $1{ }^{\text {a }}$ Sala, sentencia de casación en el fondo de 21 de enero de 2008, rol 5055-06, Nº Microjuris: MJJ18629, en su considerando noveno resolvió: el deudor no puede excusarse del cumplimiento de su obligación alegando "un exceso de onerosidad en su prestación, aún que aquel le impusiese una conducta y un desembolso de dinero originalmente no previsto" ya que "no es causa de exoneración la mayor dificultad, aunque ésta aumente la intensidad".

${ }^{35}$ Sin perjuicio del rechazo casi unánime a la teoría de la imprevisión, el artículo 2003 No 2 del Código Civil entrega de manera excepcional ciertas luces respecto de una posible 
de preferencia un juez, pueda modificar el contenido de las obligaciones acordadas entre las partes como consecuencia del cambio sustancial su conmutatividad.

En resumen, mientras un individuo del género determinado exista, la obligación subsiste. No es relevante la conducta desplegada por el deudor para configurar el incumplimiento de una obligación de dar una cosa de género determinado.

a.2) Obligaciones de dar una suma de dinero y su incumplimiento contractual

El pago de una suma de dinero es, por esencia, una obligación de género $y$, por ende, lo descrito precedentemente es aplicable para este tipo de situaciones. Así, la única forma de poder cumplir con ellas es acreditando que ha hecho entrega de la suma debida al acreedor. Como señaló Fernando Fueyo, para cumplir con la obligación

"debe pagarse, en consecuencia, atendiéndose única y exclusivamente al valor numérico asignado al disco metálico o al papel moneda" ${ }^{36}$.

En igual sentido, se ha fallado que por el solo incumplimiento del pago de las rentas adeudadas, esto es, por el simple hecho de no proceder a su íntegro y oportuno pago, hay incumplimiento de la obligación contractual ${ }^{37}$, lo mismo para el caso de no haber efectuado el pago del precio de las mercaderías vendidas ${ }^{38}$.

Como puede apreciarse, para efectos de la inejecución de esta clase de obligaciones de dar una suma de dinero, tanto la doctrina como la jurisprudencia prescinden del juicio de reproche sobre la conducta del deudor para la configuración del hecho generador, no reconociéndole la facultad de probar que se comportó diligentemente para acreditar el cumplimiento. Es más, si a la verificación de una obligación de pago

aplicación. Véase al respecto Claudio Illanes Ríos, "El contrato de construcción a suma alzada", en Publicaciones del Colegio de Abogados de Chile, Santiago, Colegio de Abogados de Chile A.G., junio de 1996, p. 18.

${ }^{36}$ Fueyo (n. 1), p. 136

${ }^{37}$ Corte de Apelaciones de Concepción, fallo de 20 de octubre de 2008, rol causa: 3753-2006, No identificador Microjuris: MJJ18927. Dicha sentencia resuelve una demanda sobre incumplimiento de contrato de arriendo por no pago de las rentas pactadas, estableciendo que éste queda configurado por el solo hecho del no pago, esto es, por no ejecutar la prestación debida.

${ }^{38}$ Corte Suprema, fallo casación en el fondo, de 27 de diciembre de 2007, rol 43572006, $\mathrm{N}^{\circ}$ Microjuris MJJ 6606, en especial su considerando $19^{\circ}$. 
de una suma de dinero se le sujeta a la posible conducta que pudiera desplegar el deudor, significaría sujetar el cumplimiento a un elemento accidental, a una condición, a hacer algo para poder pagar o a pagar sólo si ocurre algo. Esto último es condicionar el pago de una suma de dinero a un hecho futuro e incierto, lo cual no es un elemento de la esencia de este tipo de obligaciones. No es posible para el demandado, en un juicio de cobro de un mutuo pagadero en cuotas, argumentar que ha dejado de pagarlas a causa de la pérdida de su trabajo y, en consecuencia, de su remuneración. En dicho caso no produce efecto la prueba por parte del deudor que se ha comportado diligentemente en la búsqueda de un nuevo trabajo remunerado y que, a pesar de no tener dinero, ha hecho todo lo posible, como lo haría cualquier padre de familia, para poder cumplir con lo pactado.

En suma, no es relevante ser diligente en el cumplimiento de una obligación de dar una suma de dinero, pues sólo es posible acreditar su ejecución y, por ende, su cumplimiento, efectuando la enajenación de lo debido $^{39}$.

\section{a.3) Obligaciones de dar una especie o cuerpo cierto y su incumplimiento contractual}

42 Como ya hemos afirmado, la obligación de dar se cumple transfiriendo el dominio de la cosa debida. En el evento que lo que se deba sea una especie o cuerpo cierto, el $C C$ impone nuevas obligaciones al deudor: el cuidar y conservar la cosa hasta su entrega, según se establece en sus artículos 1548 y 1549. Así, una de las diferencias entre la obligación de dar un individuo de género determinado y una especie o cuerpo cierto radica en el número de prestaciones que recaen sobre el deudor. En el primer caso sólo se debe transferir el dominio. En el segundo, es necesario, además, cuidar y conservar lo que se va a transferir ${ }^{40}$. Así, el inejecución podrá verificarse sobre la base de una o a las dos prestaciones debidas: o porque no se dio la cosa, o porque la cosa dada presenta deterioros o daños producto de que no se cuidó y no se conservó la cosa de manera diligente.

${ }^{39}$ La única excepción a lo señalado sería la promesa de que un tercero efectúe un pago determinado. Sin embargo, dicha obligación es por esencia de hacer y no de dar. Esto porque el deudor se obliga a que un tercero realice algo, el pago, enmarcando dicha obligación en la promesa de hecho ajeno, contrato que por su naturaleza es fuente de una obligación de hacer en donde el deudor se obliga a realizar todo lo posible para que un tercero efectúe algo.

${ }^{40}$ Claro Solar (n. 1), tomo x, N ${ }^{0}$ 351, p. 351, establece que el deudor de una obligación de dar una especie o cuerpo cierto está obligado a conservar la cosa que tiene en su poder empleando en su custodia "la debida diligencia a fin de evitar que la cosa se deteriore o se destruya y se pierda; las obligaciones de género no tiene tal obligación”. 
No tenemos dudas de que la obligación de cuidado y de conservación sobre la cosa debida exige al deudor comportarse sobre la base de un parámetro de conducta determinado, ya que en caso de pérdida o deterioro de la cosa, su compartimiento se verá sometido a un examen o juicio de valor del cual se podrá concluir si es o no es responsable por los daños y deterioros que sufrió la cosa ${ }^{41}$. Por el contrario, en el cumplimiento de la obligación de dar una especie o cuerpo cierto, se debe determinar si es posible cumplir con ella comportándose de manera diligente a pesar de no realizar la entrega y la transferencia del cuerpo cierto. $\mathrm{Al}$ respecto, se ha fallado que cuando se debe transferir el dominio de una cosa y ello no se realiza, "la imposibilidad de cumplir ha de ser absoluta" 42 para que dicha inejecución exima de responsabilidad al deudor. En igual sentido, se ha señalado que éste sólo puede eximirse de responsabilidad probando "un hecho sobreviniente, imprevisto e independiente de la voluntad del deudor" " , concluyendo que sólo un elemento externo a su conducta puede eximirlo de responsabilidad. Ahora bien, se debe precisar que dichos elementos externos destruyen el nexo causal entre el daño y el hecho generador, logrando una desconexión entre éstos, imposibilitando que se configure otro de los elementos necesarios para establecer la responsabilidad contractual. Efecto de ello es la configuración de una eximente de responsabilidad civil y no la prueba de que se cumplió la obligación debida producto de un comportamiento diligente. Así, el incumplimiento de una obligación de dar una especie o cuerpo cierto únicamente puede ser desvirtuada destruyendo el nexo causal de la responsabilidad contractual y no su hecho generador, el cual se configura por la sola contravención de lo prometido ${ }^{44}$, independiente de la conducta desplegada por el deudor.

${ }^{41}$ Más adelante analizaremos las obligaciones de cuidado y de conservación, junto con sus alcances.

${ }^{42}$ Corte Suprema, $1^{\text {a }}$ Sala, sentencia de casación en el fondo de 21 de enero de 2008, rol 5055-06, N Microjuris: MJJ18629. Cabe recalcar la severidad de la sentencia, donde se afirma que "En las obligaciones de dar, sea una especie o un género y en las de ejecutar un hecho, la imposibilidad de cumplir ha de ser absoluta", considerando noveno.

${ }^{43}$ Véase a Rodríguez Grez (n. 1), No 336, p. 173. Cabe mencionar que dicho autor es de opinión de que el incumplimiento de la obligación de dar se basa en la culpa. Sin embargo, argumenta que el no cumplimiento de la transferencia del dominio sólo puede depender de hechos ajenos a la conducta desplegada por el deudor para que no genere responsabilidad en él. Así, el juicio de reproche sobre su conducta procede ya no examinando la conducta misma de éste, sino que analizando elementos externos, sin observar la diligencia desplegada.

${ }^{44}$ Corte Suprema, $1^{\text {a }}$ Sala, considerando $9^{\circ}$ de sentencia de casación en el fondo de 21 de enero de 2008, rol 5055-06, No Microjuris: MJJ18629. Los hechos son los siguientes: En un contrato de arriendo con opción de compra, durante la vigencia del arriendo, la cosa arrendada es incautada por un tribunal de aduanas. Tras la llegada del plazo para ejercer la 
En síntesis, lo relevante en la obligación de transferir una especie o cuerpo cierto es que trae consigo dos obligaciones. Por un lado, la de cuidar o conservar la cosa debida, que se cumple desplegando una conducta tipo que no asegura por sí sola la perfecta conservación y existencia de la cosa $\mathrm{y}$, por el otro, la de dar, que únicamente es posible cumplir entregando y transfiriendo el dominio ${ }^{45}$.

b) La obligación de entregar y de restituir y su incumplimiento contractual

La obligación de entregar y de restituir son actos jurídicos que permiten a quien recibe la cosa entregada o restituida gozarla materialmente, sea a título de propietario-poseedor o de mero tenedor, según sea el caso. Por ejemplo, el vendedor, el arrendador y el pignorante entregan la cosa vendida, arrendada o pignorada ${ }^{46}$, y el arrendatario, el comodatario y el pignoratario restituyen la cosa recibida en arrendamiento, en comodato o en prenda ${ }^{47}$. La pregunta, entonces, es determinar si el cumplimiento de la obligación, que consiste en entregar o en restituir la cosa debida, se verifica únicamente entregándola o restituyéndola, o sólo basta para cumplir con dicha obligación el desplegar una conducta consistente en hacer todo lo posible para entregarla o restituirla, a pesar de que esto no ocurra.

$44 \quad \mathrm{Al}$ respecto, la Excma. Corte Suprema entiende que el vendedor de un inmueble tiene que ejecutar dos prestaciones para cumplir con su obli-

opción de compra, el arrendatario-comprador ejerce la opción y se configura así el contrato de compraventa. El arrendador-vendedor manifiesta que no puede cumplir con la venta porque la cosa objeto del contrato (un vehículo motorizado) está incautado. La Excma. Corte Suprema resuelve, en su considerando $9^{\circ}$, que la incautación no es un caso fortuito porque es posible de resistirlo y que por el mero hecho de la no enajenación y entrega se incumplió la obligación contractual. Asimismo, señala que la obligación de dar procede siempre salvo que se pruebe un hecho ajeno que haga imposible dar la cosa. Por otra parte, dicha sentencia resulta relevante en cuanto dispone que el arrendador tiene la obligación de permitir el goce de la cosa al arrendatario, siendo ésta una obligación de diligencia. Como se establece en el considerando $8^{\circ}$, el deudor debe emplear en "el salvamento de la especie arrendada (desde Aduana) la diligencia de un buen padre de familia”, para señalar, en el considerando $10^{\circ}$ que se "debe liberar al arrendatario de toda perturbación o embarazo en el goce de la cosa”. Así, dicha sentencia distingue las obligaciones que emanan para el arrendador y para el vendedor, según su respectivo contrato.

${ }^{45}$ Esto último, salvo que la cosa sea destruida por un hecho no imputable al deudor. Ahora bien, se debe tener presente que la prueba de la destrucción de la cosa se relaciona con la obligación de cuidado y conservación, no con la de transferir el dominio. Es por ello que se debe acreditar si la cosa se destruyó por culpa o sin culpa del deudor. Todo lo anterior es sin perjuicio de que las partes contratantes regulen o fijen la entrega a determinados parámetros o condiciones.

${ }^{46}$ Siempre que la prenda sea con desplazamiento.

${ }^{47}$ Siempre que la prenda sea con desplazamiento. 
gación. Por un lado, debe transferir el dominio a través de la inscripción conservatoria y, por el otro, debe entregar materialmente la cosa vendida ${ }^{48}$. El efecto de dichas dos obligaciones es que

"si falta una de esas entregas, háyase o no realizado la otra, el comprador tendrá derecho para pedir el cumplimiento del contrato o su resolución y, en ambos casos, con la correspondiente indemnización de perjuicios" ${ }^{\prime 9}$.

Es decir, habrá incumplimiento no ejecutando cualquiera de las dos entregas, sin importar la conducta ni el nivel de diligencia que haya desplegado el vendedor en la ejecución de las mismas.

Con igual criterio se ha fallado, para efectos de un contrato de arrendamiento, que sólo por la no entregar la cosa arrendada hay incumplimiento de la obligación de entregar por parte del arrendador ${ }^{50}$. Lo mismo ocurre para afectos de determinar si se ha cumplido o no con la restitución de la cosa arrendada por parte del arrendatario. El $C C$ no exige valorar la conducta del arrendatario para configurar el hecho generador del incumplimiento contractual al disponer que la "restitución de la cosa raíz se verifica desocupándola enteramente, poniéndola a disposición del arrendador y entregándole las llaves", según dispone su artículo 1948. Esto ha sido confirmado por la Excma. Corte Suprema, al fallar que dicho incumplimiento se configura al acreditar la no restitución por parte del arrendatario de la cosa arrendada, resolviéndose:

"establecido el incumplimiento contractual por la parte de la demandada, traducido en la omisión en la entrega de los bienes señalados en la parte expositiva de este fallo" ${ }^{51}$.

${ }^{48} 1^{\text {a }}$ Sala de la Excma. Corte Suprema, fallo de casación en el fondo, 28 de julio de 2009, rol 2161-2008, No Microjuris: MJJ20721. En su considerando $9^{\circ}$ resolvió: "el vendedor se encuentra obligado tanto a efectuar la entrega legal que se verifica por medio de la correspondiente inscripción conservatoria como a realizar la entrega material del bien objeto del contrato de compraventa". Dicho fallo hace mención que la dualidad de entregas se ha aplicado desde hace más de noventa años.

${ }^{49}$ Ibid.

${ }^{50}$ Corte Suprema, fallo de casación en el fondo y en la forma, 29 de julio de 2010, rol 6918-2008, No Microjuris: MJJ24429. Los hechos consistieron en que el arrendatario no entregó los 324 elementos publicitarios en el período y en los lugares precisados en el contrato respectivo, estableciendo la Excma. Corte que sólo por la no entrega, hubo incumplimiento de la obligación principal.

${ }^{51} 1^{\text {a }}$ Sala, Corte Suprema, fallo de casación en el fondo y forma de 30 de junio de 2008, rol 5857-2006, $\mathrm{N}^{\mathrm{o}}$ Microjuris: MJJ 17403. El fallo de casación establece que por la sola constatación de la no restitución del inmueble, el deudor incumplió su 
En otras palabras, el hecho generador del incumplimiento de la obligación de restitución de una cosa arrendada se configura por la sola acreditación de la no restitución, sin importar la conducta desplegada por el arrendatario.

Lo relevante en la obligación de entregar ${ }^{52}$ y de restituir es que si éstas no se efectúan, se configura por esa sola circunstancia el hecho generador del incumplimiento de la obligación contractual, no pudiendo el deudor acreditar su cumplimiento probando que ha actuado diligentemente a pesar de la no entrega o la no restitución de la cosa debida.

c) La culpa en los contratos de compraventa, de arrendamiento, de depósito y de comodato

Hemos visto que en las obligaciones de dar, de entregar y de restituir, el hecho generador del incumplimiento contractual se configura prescindiendo de la valoración de la conducta desplegada por el deudor. A pesar de ello, el mismo $C C$ habla de la culpa del vendedor, del arrendatario, del arrendador, del depositario, etc., en diferentes artículos. Dado lo anterior, ¿cómo conjugar la existencia de la culpa contractual y de un hecho generador del incumplimiento que prescinde de la culpa del deudor para configurarlo?

$46 \quad$ La respuesta radica en que cuando se está frente a una obligación de dar, de entregar o de restituir un cuerpo cierto pesa sobre el deudor una segunda: el cuidar, conservar y guardar la cosa debida. Dichas obligaciones de cuidado, de conservación y de guarda obligan al deudor de la cosa que se entregará o se restituirá a desplegar una conducta diligente en el cuidado, en la conservación y en el uso de la cosa debida.

obligación de restitución. Así consta en su considerando $21^{\circ}$, el cual señala: "establecido el incumplimiento contractual por la parte de la demandada, traducido en la omisión en la entrega de los bienes señalados en la parte expositiva de este fallo". Es decir, por la sola constatación de la no entrega hay incumplimiento. Los hechos acreditados en autos consistieron en que se restituyó el inmueble, pero sin doscientos de los 384 bienes muebles que comprendían la cosa arrendada.

${ }^{52}$ El incumplimiento de la obligación de entregar se acredita por la sola constatación de su inejecución. Ahora bien, el artículo 1925 y el inciso $1^{\circ}$ del artículo 1926, ambos del $C C$, someterían la obligación de entregar la cosa arrendada por parte del arrendador a un juicio o valoración de la conducta del arrendador al hablar expresamente de la culpa del arrendador. Sin perjuicio de ello, el inciso $2^{\circ}$ del artículo 1926, priva al arrendador de acreditar el cumplimiento de su obligación a través de la prueba de un comportamiento diligente, al permitirle al arrendatario desistirse del contrato con indemnización de perjuicios en el evento de que a causa del retardo en la entrega de la cosa arrendada haya una notable disminución en la utilidad del contrato para el arrendatario. Lo anterior, no podrá ser desvirtuado por el arrendador acreditando su debida diligencia o ausencia de culpa. 
Desde dicho punto de vista se entienden y tienen su real sentido y campo de aplicación los artículos 1486, 1548, 1549, 1670, 1671, 1672, 1927, 1939, inciso $4^{\circ}$ del 1947, 2178, inciso $2^{\circ}$ del 2219 y 2394 del $C C$. Éstos tratan sobre los daños, pérdidas y perjuicios que sufre la cosa que deberá ser entregada o restituida. De igual manera lo ha entendido la Excma. Corte Suprema, sea para el caso de que la cosa debida haya sido destruida en un incendio o para el caso donde la cosa debida haya desaparecido por un acto de un tercero mientras la cosa estaba en posesión o bajo la mera tenencia del deudor cuidador y conservador. Así, se ha resuelto que el deudor del cuerpo cierto no es responsable de la destrucción de la cosa debida en un incendio si "prueba debida diligencia en su conducta" ${ }^{53}$ ya que por ser diligente en el cuidado y en su conservación "se entiende que sí cumplió con su obligación" ${ }^{54}$. Asimismo, para el caso de la pérdida de los bienes inventariados que se debían restituir y que no se restituyeron producto de que un tercero los sustrajo, se resolvió que el demandado no es responsable tras probar que

"el deudor arrendatario demandado cumplió todas las diligencias de custodia, cuidado, manutención y conservación a que se encontraba obligado en virtud del contrato de arrendamiento" ${ }^{55}$.

Como se puede apreciar, la pérdida de la cosa debida sin culpa del deudor, sea porque la cosa se destruyó o porque un tercero la sustrajo, produce dos efectos: por una parte, tras la prueba de la debida diligencia en el cuidado y conservación de la cosa, el demandado acredita el cumplimiento de su obligación de cuidado y conservación a pesar de la pérdida o de la destrucción de la cosa debida y, por la otra, como efecto directo de la pérdida o sustracción de la cosa sin culpa, se extingue ${ }^{56}$ la obligación de entregar o de restituir la cosa debida objeto del contrato ${ }^{57}$.

${ }^{53}$ Para el caso de la destrucción de la cosa debida en un incendio véase Corte Suprema, fallo de casación en el fondo de 20 de junio de 1949, en RDJ, tomo XLVI, Santiago, 1949, $2^{\mathrm{a}}$ parte, sec. 1, p. 533 y ss.

${ }^{54}$ Ibid.

$551^{\text {a }}$ Sala Corte Suprema, fallo casación en el fondo de 28 de julio de 2008, rol 25732007, No Microjuris: MJJ 17724, considerando $5^{\circ}$.

${ }^{56}$ La extinción de la obligación de entregar o de restituir no procede si la cosa debida subsiste a pesar de sufrir daños o perjuicios. En dicho escenario, el deudor deberá entregar o restituir la cosa debida para cumplir con la entrega o restitución y, será o no responsable de dichos daños y de dichos perjuicios dependiendo de si acredita o no que actuó con la debida diligencia en el cuidado y en la conservación de la cosa debida.

${ }^{57}$ Tras el análisis de las sentencia de la Excma. Corte Suprema de 28 de julio de 2008 y de 20 de junio de 1949, la pérdida y la destrucción de la cosa debida, en ambos casos, se debió o a un caso fortuito o a un caso de fuerza mayor. A pesar de que ambas sentencias 
Lo resuelto por la Excma. Corte Suprema se ajusta perfectamente al mecanismo que describió Robert J. Pothier en su Tratado, del cual se desprende la existencia de las señaladas dos obligaciones. Así, cuando describe que se debe diligencia en el cuidado de la cosa, pero que, a la vez, sólo es posible eximirse de la obligación de entregar o de restituir probando un hecho ajeno que atenta contra el elemento nexo causal, se reconoce en forma explícita la exclusión de la culpa en una de las dos obligaciones. Describe que en aquélla de cuidado y de conservación, el deudor no será responsable de los daños que sufra la cosa si acredita que actuó diligentemente en el cuidado y conservación, cumpliendo así con dicha obligación. En cambio, en el evento de que el deudor no entregue o no restituya la cosa debida, no podrá acreditar el cumplimiento probando una debida diligencia, sino que sólo podrá eximirse de dicha obligación acreditando un hecho ajeno a su voluntad, como lo es el caso fortuito, que destruye el nexo causal. Es decir, para efectos del cumplimiento de la obligación de entregar o de restituir, Robert J. Pothier excluye la posibilidad de que el deudor pueda avalar la ejecución, acreditando su debida diligencia a pesar de no haber realizado la entrega o la restitución ${ }^{58}$. Esto último significa que, si no se

podrían considerar que el deudor no fue responsable producto de que no se configuró el nexo causal tras la prueba de un incendio y de una sustracción, dicho racionamiento no sería del todo correcto. Ello porque en ambos casos se acreditó la debida diligencia en el cuidado y en la conservación de la cosa. Se debe partir de la base que cuando la cosa debida se destruye o se pierde, la causa será o la culpa del deudor en el cuidado y conservación o un hecho ajeno superior a la diligencia de éste. Ahora, el Código presume que los daños, los perjuicios, la pérdida o la destrucción son por la culpa del deudor, lo que significa que si éste invierte la presunción a través de la prueba de su debida diligencia en el cuidado y en la conservación, los daños, los perjuicios, la pérdida o la destrucción serán atribuibles a un caso fortuito o a una fuerza mayor. Así, tras desvirtuar la presunción de culpa, se concluye que la pérdida de la cosa se debió a un hecho ajeno, como un incendio o una sustracción, lo que trae como consecuencia la extinción de la obligación posterior, la de entrega o de restitución, la cual no puede realizarse por falta de objeto.

${ }^{58}$ Sobre la dualidad de obligaciones véase René Demogue, Traité des Obligations en général. Sources des Obligations, Paris, Rousseau, 1925, tome v, No 1237, p. 542, sostiene que: "Dans les contrats, on trouve des obligations de résultat et des obligations de moyens". Respecto de Robert J. Pothier y el contenido de la obligación de dar, véase (n. 19), No 141, p. 66. Para efecto de la obligación de dar y para efecto de si lo que se debe dar es una especie o cuerpo cierto $\mathrm{N}^{\mathrm{o}} 142$, p. 66. Sobre la influencia de Robert J. Pothier en el Código Civil francés véase Claro Solar (n. 1) quien sostiene: "El Código Civil francés se refiere a la prestación de la culpa solamente al tratar de la obligación de velar por la conservación de la cosa en la obligación de dar. Ha influido seguramente en este procedimiento de sus redactores el ejemplo del Pothier que se refiere también a la prestación de la culpa en los efectos de esta clase de obligaciones", $\mathrm{N}^{0} 1049$, p. 499. Para el caso del contrato de venta, véase Robert J. Pothier, Euvres de Pothier, Traité de contrat de vente, par M. JeanJospeh Bugnet, Paris, Imprimerie de Cosse, 1847, tome III, No 54, 56 y 58. Para efectos de la restitución de la cosa arrendada, véase Robert J. Pothier, Euvres de Pothier, Traités 
entrega o no se restituye la cosa debida se configura el hecho generador del incumplimiento contractual, donde el deudor únicamente podrá eximirse de su responsabilidad destruyendo el nexo causal acreditando que la no entrega o la no restitución se debió a un eximente de responsabilidad. En cambio, para el cumplimiento de la obligación de cuidado sólo se exige haber actuado con la debida diligencia independiente del resultado.

Así, entonces, como lo ha señalado la Excma. Corte Suprema y como se entiende del modelo descrito en el Tratado de Robert J. Pothier, se concluye que para que el deudor incumpla su obligación de cuidado y de conservación es necesario valorar su conducta para constatar así su culpa o su falta de diligencia en el cuidado, en la conservación o en la guarda de la cosa debida ${ }^{59}$. Efecto de lo anterior es que el hecho generador del incumplimiento contractual de la obligación de cuidado, de conservación y de guarda se configura tras la suma de dos elementos:

- la prueba de la existencia del daño, del perjuicio, de la destrucción o de la pérdida de la cosa debida y

- que dicho daño, que dicho perjuicio o que dicha pérdida o dicha destrucción sea consecuencia de una conducta negligente por parte del deudor ${ }^{60}$.

Como se estableció en los fallos citados, si el deudor se comportó diligentemente podrá acreditar el cumplimiento de su obligación contractual de cuidado y conservación a pesar de que la cosa se haya destruido, haya desaparecido o haya sufrido daños y perjuicios.

En resumen, de lo analizado en las letras $a, b$ y $c$ precedentes se concluye que el deudor de una obligación de entregar o de restituir una

de Contrat Louage, du Contrat de bail à rente, du Contrat de société, des Cheptels des Contrats des louages maritimes, du Contrat de change, par M. Jean-Joseph Bugnet, Paris, Imprimerie de Cosse, 1847, tome IV, donde se establece: "Le locataire est déchargé de l'obligation de rendre la chose, si la chose a péri sans sa faute; mais il doit enseigner et justifier comment elle a péri, autrement elle est présumée avoir péri par sa faute”, $\mathrm{N}^{\circ} 199$, p. 73.

${ }^{59}$ Como ya hemos indicado, la regla general es que nuestro Código Civil presume la culpa del deudor cada vez que se acredita la existencia de la obligación. Para invertir el peso de la presunción, el demandado deberá acreditar o que ha ejecutado la prestación debida o que ha actuado diligentemente y de esta manera probar que cumplió su obligación.

${ }^{60}$ Existe una excepción a la regla donde el deudor puede acreditar el cumplimiento a través de la prueba de su debida diligencia en el cuidado y conservación de la cosa a pesar de no poder entregarla o de no poder restituirla, si la causa fue un hurto o fue un robo. Dicha excepción está contenida en el artículo 2242 del $C C$, que regula la responsabilidad por custodia del posadero sobre las cosas robadas o hurtadas que le fueron dejadas por sus alojados, por el cual el posadero es responsable independientemente de la diligencia que haya empleado en su custodia, cuidado y conservación. Véase Alejandro GuzMán BRITO, "La responsabilidad objetiva por custodia en el derecho romano y en el derecho moderno, con una referencia especial a la regla periculum est emptoris", en Revista Chilena de Derecho, vol. 24, No 1, Santiago, 1997, p. 191. 
especie o cuerpo cierto, sea a título de compraventa, de arrendamiento, de comodato, etc., tendrá al menos dos obligaciones: por un lado, deberá entregar o restituir la cosa debida y, por el otro, deberá cuidarla, conservarla y guardarla de manera diligente hasta su entrega o restitución, para que con esa diligencia se eviten daños o perjuicios en la cosa o se evite la pérdida o la destrucción. Dicha dualidad de obligaciones ha sido reconocida por la jurisprudencia en materia de arrendamiento ${ }^{61}$, de comodato $^{62}$ y de depósito ${ }^{63}$.

\section{d) Obligación de no hacer y su incumplimiento contractual}

Respecto de las obligaciones de no hacer, cabe preguntarse si tras realizar lo que estaba prohibido, es posible que el deudor no sea responsable de dicha infracción, acreditando, como establece el modelo del artículo 1547 del $C C$, una conducta diligente. Por ejemplo, des posible ser diligente infringiendo la obligación de no hacer consistente en no talar un bosque, a pesar de haberlo talado?, o si una persona se obligó a no celebrar un contrato determinado, cies posible que pueda acreditar su debida diligencia a pesar de haber celebrado el contrato prohibido? La respuesta a dichas preguntas la encontramos en la parte final del artículo 1557 del $C C$, el que establece que en la obligación de no hacer, "se debe indemnización de perjuicios...desde el momento de la contravención". Así, la sola acreditación de haber realizado o ejecutado lo que estaba prohibido basta para configurar el incumplimiento contractual. En igual sentido se ha pronunciado la doctrina, la que ha señalado que el deudor mientras

${ }^{61} 1^{\text {a }}$ Sala de la Corte Suprema, fallo de casación en el fondo y forma de 30 de junio de 2008, rol 5857-2006, Nº Microjuris: MJJ 17403. Dicha sentencia confirma lo establecido en los incisos $1^{\circ}$ y $4^{\circ}$ del artículo 1947 del $C C$, al tratar separadamente la obligación de restituir y la de cuidado. El fallo reconoce que el incumplimiento de la obligación de restitución se configura por la no restitución de la cosa debida. En cambio, para determinar si se incumplió o no con aquélla de cuidado y conservación, los Jueces valoran la conducta del deudor para determinar si actuó de modo diligente o con culpa.

${ }^{62}$ Corte Suprema, fallo de casación en el fondo de 4 de abril de 1995, No Microjuris RDJ 1526, autos caratulados Sony Corporation con Sociedad Cantolla y Cía. S.A.C. e I. Dicho fallo, en sus considerandos $10^{\circ}$ y $11^{\circ}$, distingue expresamente la dualidad de prestación en la obligación del comodatario. Manifiesta en su considerando $10^{\circ}$ : "el comodatario es obligado a emplear el mayor cuidado en la conservación de la cosa y responde hasta de culpa levísima" y en su considerando $11^{\circ}$, expresa: "en el evento de que el comodatario no pudiese restituir las cosas objeto de los vales de prenda será responsable de ello".

${ }^{63}$ Véase a Jean Carbonnier, citando un fallo de la Corte de Casación Francesa (Civ. 1, 28 mai 1984, Bull., N 173), señala que el caso del depósito ordinario es útil para explicar la dualidad de obligaciones, donde "restituer la chose est une obligation de résultat, la restituer en bon état suggère une obligation de moyens", Jean CArbonnier, Droit Civil, $1^{\mathrm{a}}$ ed. "Quadrige", Paris, P.U.F., 2004, vol. II, No 1075, p. 2.197. 
"no ejecuta lo prohibido está cumpliendo. Pero si viola el compromiso, realizando lo que no debía hacer... se produce directamente la infracción...”"

debiendo, por tanto, los perjuicios y sus intereses ${ }^{65}$.

En otras palabras, para configurar el hecho generador del incumplimiento contractual de una obligación de no hacer sólo basta acreditar la infracción, prescindiendo de la valoración de la conducta del deudor.

e) Incumplimiento de una obligación contractual que consta en título ejecutivo

La característica principal del denominado título ejecutivo es que por sí mismo acredita la existencia de la obligación pactada entre los otorgantes del título. En un juicio ejecutivo, a diferencia de uno ordinario, no es necesario probar la existencia de la obligación, porque el título es prueba de ello. Teniendo claro lo anterior, cabe hacernos la pregunta que nos hemos venido planteando en el sentido que si es posible acreditar el cumplimiento de la obligación que consta en un título ejecutivo acreditando que se actuó diligentemente o sin culpa a pesar de no realizar la prestación debida. La respuesta es negativa, ya que únicamente es posible acreditar el referido cumplimiento a través de la acreditación de la observancia de dicha obligación, independiente de la conducta desplegada por el deudor. Es por ello que "la acción ejecutiva no exige un incumplimiento culpable del deudor" ${ }^{\prime \prime}$.

En síntesis, se prescinde de la valoración de la conducta del deudor para acreditar el incumplimiento de la obligación que consta en un título ejecutivo.

\section{f) Del saneamiento de los vicios redhibitorios}

Al regularse la institución de los vicios redhibitorios como una obligación de garantía por la calidad de la cosa vendida, entregada en arriendo, en comodato o en mutuo, el $C C$ estableció que tanto el vendedor, el arrendador, el comodante y el mutuante serán responsables de los vicios ocultos,

${ }^{64}$ Fueyo Laneri (n. 1), p. 440.

${ }^{65}$ Pothier (n. 19), señala: “L'effet de l'obligation qu'une personne a contractée de ne pas faire quelque chose, est que, si elle le fait, elle est tenue des dommages et intérêts résultant du préjudice qu'elle a causé en faisant cela, à celui envers qui elle s'était obligée de ne le pas faire", $\mathrm{N}^{\mathrm{o}} 148$, p. 69

${ }^{66}$ Véase Enrique Barros Bourie, "La diferencia entre 'estar obligado' y 'ser responsable' en el derecho de los contratos”, en Hernán Corral Talciani y María Sara Rodríguez Pinto (coords.), Estudios de Derecho Civil II, Santiago, LexisNexis, 2007, p. 730. 
que, según el artículo 1858 del $C C$, hagan que la cosa no sirva para su uso natural o sólo sirva imperfectamente.

Quien entrega la cosa, en caso de que se configuren las condiciones exigidas para que un vicio sea calificado de oculto, no podrá oponer como medio para acreditar el cumplimiento de su obligación de saneamiento el hecho de haberse comportado diligentemente, y deberá responder siempre frente al comprador, al arrendatario, al comodatario y al mutuario a la solicitud de rebaja del precio o de rescisión del contrato, como lo establece el artículo 1860 del $C C$. Así lo ha interpretado la jurisprudencia al fallar que "el vendedor siempre debe responder de los vicios ocultos de la cosa vendida" ${ }^{67} \mathrm{y}$ en igual sentido se ha pronunciado la doctrina, al indicar que "la protección del acreedor articulada a través de la acción redhibitoria y quanti minoris es objetiva" ${ }^{68}$. El hecho de que el deudor responda siempre por los vicios ocultos anteriores al contrato respectivo, hace que la obligación de saneamiento sea más severa con éste en comparación con una obligación objetiva propiamente tal. Lo anterior porque la obligación de saneamiento hace responsable al deudor, incluso, si el vicio oculto fue causado por un caso fortuito, por un caso de fuerza mayor o por un hecho de un tercero. La obligación de saneamiento, al ser de garantía, hace responsable al deudor de hechos que, por regla general, son constitutivos de eximentes de responsabilidad.

En resumen, a través de la institución del saneamiento de los vicios ocultos, Andrés Bello estableció otra obligación contractual cuyo hecho generador del incumplimiento se configura prescindiendo de la diligencia del deudor.

\section{g) Ciertas obligaciones de hacer}

Hemos visto que en las obligaciones de dar y en de no hacer, el incumplimiento contractual prescinde de la culpa del deudor para configurar

${ }^{67}$ Véase Corte Suprema, fallo de casación en el fondo y forma de 11 de abril de 2002, rol Nº96-01, en su considerando $7^{\circ}$.

${ }^{68}$ Iñigo de la Maza Gazmuri, "A propósito del artículo 1861", en Facultad DE DERecho, Universidad de Concepción, Estudios de Derecho Civil v, Santiago, AbeledoPerrot, 2010 , p. 457. El hecho de que la acción de indemnización por los vicios ocultos sea de carácter subjetivo, no se relaciona con la culpa del deudor sino, más bien, con su comportamiento doloso o equiparable al dolo. Así, por ejemplo, véase a Enrique BARRos BoURIE, Tratado de responsabilidad extracontractual, Santiago, Editorial Jurídica de Chile, 2007, No 814, p. 1.019, señala: "El propio Código establece expresamente la responsabilidad del vendedor que actuó con dolo, porque conocía los vicios y no los informó, o que actuó con culpa grave, porque no los hizo saber debiendo conocerlos atendida su profesión u oficio", teniendo presente que, como se desprende el artículo 1465, siempre se responderá del dolo y, en consecuencia, será una responsabilidad subjetiva, la cual debe probarse siempre salvo texto legal expreso. 
el hecho generador, por lo que el mecanismo establecido en el inciso $3^{\circ}$ del artículo 1547 del $C C$ no es aplicable. Ahora bien, cabe preguntarse si dicho mecanismo tiene aplicación general en el caso del incumplimiento de una obligación de hacer o sólo se utiliza para el caso de ciertas obligaciones contractuales de hacer. Nuestra respuesta es que se aplica sólo a alguna de ellas ya que existen obligaciones de hacer, tanto legales como jurisprudenciales, cuya configuración del hecho generador del incumplimiento contractual prescinde de la culpa del deudor.

Dentro de las obligaciones legales de hacer que prescinden de la culpa para configurar el hecho generador se encuentran las de entregar y de restituir la cosa debida, ya analizadas. Dentro de las obligaciones jurisprudenciales que prescinden de la culpa contractual como elemento necesario para configurar la responsabilidad del deudor encontramos las siguientes: la obligación de construir un inmueble sin vicios de construcción y la de prestar un servicio de transporte bajo un determinado estándar de calidad. Ambas las estudiaremos a continuación.

Respecto de los vicios de construcción, la Excma. Corte Suprema ha resuelto que la obligación de hacer consistente en la ejecución de una obra se incumple si se acredita la existencia de vicios de construcción. Para nuestro máximo tribunal el hecho generador del incumplimiento se configura

"habiéndose determinado fehacientemente el incumplimiento contractual del demandado en razón de los graves desperfectos de construcción advertidos en el inmueble" ${ }^{69}$,

sin importar la diligencia que haya desplegado el deudor constructor. Asimismo, la Excma. Corte Suprema afirmó que la acreditación de una eximente de responsabilidad es la única manera posible de que éste no sea responsable de la existencia de tales vicios ${ }^{70}$. En otras palabras, para nuestro máximo tribunal la manera de no ser responsable de los vicios de construcción es por medio de la prueba de un eximente de responsabilidad que no permita la configuración del nexo causal entre el hecho generador y el daño sufrido, lo cual se acredita probando un hecho ajeno a la conducta del deudor, como lo es un caso fortuito, un hecho de un tercero o un hecho de fuerza mayor. Así, el incumplimiento de la obligación de

${ }^{69} 1^{\text {a }}$ Sala Corte Suprema, sentencia de reemplazo de recurso de casación en la forma de 11 de mayo de 2009, rol 2313-2008, NMicrojuris: MJJ 20077, considerando $2^{\circ}$.

${ }^{70} \mathrm{Op}$. cit., considerando $1^{\mathrm{o}}$ letra b), donde se constató que "el demandado no probó el haberse visto impedido de cumplir su obligación por causas ajenas a su responsabilidad”. 
construir se configura por el solo hecho de probar la existencia de vicios de construcción, siendo así una responsabilidad objetiva ${ }^{71}$.

Respecto del cumplimiento de la obligación de hacer del prestador del servicio en un contrato de prestación de servicios de embalaje, refrigeración y transporte de carga de fruta, la Excma. Corte Suprema ha resuelto que el incumplimiento contractual por parte del prestador del servicio se configura por la mera constatación de que la cadena de frío pactada no fue respetada íntegramente ${ }^{72}$. En otras palabras, por el solo hecho de acreditar que las condiciones de temperatura acordadas no fueron respetadas en el transporte de carga desde un lugar a otro, la Excma. Corte Suprema dio por configurado el hecho generador del incumplimiento, sin que se hiciera referencia a la conducta desplegada por el deudor, excluyendo la prueba de la debida diligencia como medio para acreditar la ejecución. Con igual criterio se resolvió que en un contrato de arriendo de una bodega (container), donde un elemento de la esencia de la cosa arrendada era la capacidad de mantener a una determinada temperatura los bienes

${ }^{71}$ Véase Sergio Urrejola SANTa María, La responsabilidad profesional de los agentes de la construcción, Santiago, Lexisnexis, 2004, p.12; BARRos Bourie (n. 68), quien a pesar de no señalar expresamente que la responsabilidad es objetiva, sostiene que la obligación es de resultado ya "que se funda en una valoración objetiva de la calidad de una cosa", No 562, p. 774; Hernán Corral TALCIANI, "Responsabilidad civil en la construcción de viviendas. Reflexiones sobre los regímenes legales aplicables a los daños provocados por el terremoto del 27 de febrero de 2010", en www.microjuris.cl, $\mathrm{N}^{\circ}$ identificador MJCH_MJD387, quien afirma: "son regímenes de responsabilidad objetiva, en el sentido de que eximen al demandante de la necesidad de probar dolo o culpa en la conducta del deudor", p. 1; Patricio Figueroa Velasco y Juan Eduardo Figueroa Valdés, Urbanismo y construcción, Santiago, LexisNexis, 2006, p. 255, señalan que la obligación se "encuentra objetivada por el resultado", y que la liberación de responsabilidad procede probando un hecho que constituya un caso fortuito o fuerza mayor, y, si los vicios de construcción son atribuibles a vicios de suelo o de materiales suministrados por el dueño de la obra, el agente de la construcción no será responsable si no debió conocer dichos vicios en razón de su profesión u oficio, op. cit., p. 256. En sentido contrario a la doctrina y a la jurisprudencia, véase a Eduardo CourT Murasso, "Algunas consideraciones en torno a la responsabilidad civil por vicios de la construcción en las legislaciones de España y de Chile", en Fundación Fernando Fueyo Laneri, Estudios de Derecho Privado. Homenaje a Gonzalo Figueroa Yañez, Santiago, Editorial Jurídica de Chile, 2008, quien sostiene: "Tratándose de un sistema subjetivo de responsabilidad por daños producto de la ruina de un edificio por vicios de construcción, el demandado en sede contractual podrá eximirse de responsabilidad acreditando la diligencia o cuidado que le era exigible atendida la naturaleza del contrato, en los términos del art. 1547, inciso $3^{\circ}$ ”, p. 306.

${ }_{72} 1^{\text {a }}$ Sala Corte Suprema, fallo de casación en el fondo de 30 de septiembre de 2009, rol 2208-2008, No Microjuris: MJJ 21689. Cabe señalar que en la sentencia no se hace referencia a la culpa o a la falta de diligencia del prestador del servicio, sólo se menciona que el incumplimiento de la obligación quedó acreditada por la sola constatación de que la cadena de frío no se mantuvo durante la vigencia del contrato. 
depositados en ella, lo cual no ocurrió, la Excma. Corte Suprema resolvió que la arrendadora

"no cumplió una de las obligaciones esenciales que impone el artículo 1924 del CC al arrendador, esto es, la de mantener la cosa arrendada en estado de servir para el fin que ha sido arrendada, por lo que igualmente debe responder de los perjuicios ocasionados"73,

dando por configurado el hecho generador del incumplimiento contractual por la sola prueba de que la cosa no servía para el fin deseado, traducido en la no mantención de la temperatura requerida.

En suma, existen obligaciones de hacer cuyo incumplimiento no requiere de la culpa del deudor como elemento necesario para configurar la responsabilidad contractual. La prescindencia de la culpa del deudor para configurar el hecho generador tiene fuente legal y jurisprudencial. Legales, son la obligación de entregar y de restituir, las que no requieren de la culpa del deudor para configurar el hecho generador. Jurisprudenciales, son las que analizamos en la presente letra g, donde uno de los puntos en común es que el deudor es un profesional que no se obliga a desplegar una conducta tipo o una conducta abstracta sino que se obliga a prestar determinados servicios destinados a cumplir un fin específico ${ }^{74}$.

A pesar de lo anterior, no cabe confundir el carácter objetivo del incumplimiento contractual en ciertas obligaciones de hacer, con la tendencia que ha mostrado la jurisprudencia a objetivar la culpa o a entender que el deudor, en un contrato bilateral conmutativo, ya no responde bajo el parámetro de la culpa leve sino que bajo el parámetro de la culpa levísima. Dicha tendencia ha tenido en la obligación de seguridad su denominador común, cuya fuente ha sido legal, accidentes del trabajo a través de la protección eficaz, o jurisprudencial, como lo es la obligación de seguridad de los concesionarios de autopista. A pesar de que dicha tendencia ha "objetivado" la culpa, no cabe hablar de una responsabilidad objetiva, pues la obligación continúa siendo una cuyo incumplimiento se funda en la reprochabilidad a la conducta del deudor,

${ }^{73} 1^{\text {a }}$ Sala de la Corte Suprema, fallo de casación en el fondo y forma de 5 de abril de 2004, rol 3277-02, $\mathrm{N}^{\mathrm{O}}$ Microjuris MJJ 7686, considerando $13^{\circ}$.

${ }^{74}$ Respecto de la configuración objetiva del hecho generador en el incumplimiento de contratos de prestación de servicios no regulados en el Código Civil, véase la parte final del trabajo de María Sara Rodríguez Pinto, "Incumplimiento y exoneración de responsabilidad en los contratos de servicios. Los lineamientos de la responsabilidad estricta del proveedor", en Alejandro GuZMán BRITO, Estudios de Derecho Civil III, Santiago LegalPublishing, 2008, pp. 503-517. Igualmente, Carlos PiZARro Wilson, "La fuerza mayor como defensa del deudor. A propósito de la restricción de suministro de gas a Chile”, en Revista de Derecho Administrativo Económico, No 14, Santiago, 2005, pp. 115-124. 
manteniéndose siempre la posibilidad de acreditar el cumplimiento a través de la prueba de la debida diligencia. En otras palabras, es viable la ocurrencia de un accidente laboral o de un accidente en una autopista donde el empleador o el concesionario puedan acreditar el cumplimiento de su obligación de protección eficaz y de seguridad acreditando su debida diligencia ${ }^{75}$.

\section{Primera conclusión}

La doctrina nacional le otorga al artículo 1547 del $C C$ un campo de aplicación general para todas las inejecuciones de obligaciones contractuales, con independencia de si consisten en un dar, en un hacer o en un no hacer, fuertemente motivado por el contexto histórico de la noción de culpa a la época de la redacción de nuestro $C C$. Ahora bien, tras el análisis realizado al incumplimiento de las obligaciones contractuales establecidas en el $C C$, hemos podido concluir que dicho cuerpo establece un doble mecanismo de configuración del hecho generador. El primero de ellos es un mecanismo subjetivo que se configura acreditando el incumplimiento de la prestación debida más la constatación de la culpa del deudor, culpa que por regla general se presume según lo establecido en el inciso $3^{\circ}$ del artículo 1547 del $C C$. El segundo mecanismo de configuración del hecho generador es de tipo objetivo, que se acredita por el solo incumplimiento de lo prometido sin que el deudor pueda probar el cumplimiento de su obligación contractual, como lo establece el inciso $3^{\circ}$ del artículo 1547 del $C C$, mediante la prueba de su debida diligencia.

${ }^{75}$ Respecto de la responsabilidad de la concesionaria de una autopista, véase sentencia de la Corte de Apelaciones de Santiago, de 9 de junio de 2009, rol 9196-2006, N Microjuris: MJJ 20030. Se trata de un accidente sufrido por un vehículo motorizado en una autopista concesionada por la colisión con un fierro de cuatro metros que cayó de un camión de carga. La Corte resolvió: "la sociedad concesionaria de la autopista debe velar porque al momento del ingreso de éstos (sic) vehículos al área concesionada, tales vehículos deben circular en condiciones de evitar daños a terceros" y que la sociedad concesionaria sólo es diligente si "adopta medidas preventivas pertinentes, o sea, vigilancia adecuada al momento de ingresar a la autopista camiones con carga que no vaya bien instalada en tales vehículos", es decir, se debe fiscalizar preventivamente el ingreso de cada camión para evitar desprendimientos de carga a la autopista concesionada. Se entiende que la concesionaria tiene una obligación de seguridad, lo cual se traduce en un aumento en la diligencia respecto a la seguridad de la autopista concesionaria. Así, el criterio de diligencia ya no es el del hombre medio, el del buen padre de familia, sino de aquél que es capaz de evitar casi todo. Respecto de la obligación laboral de protección eficaz se establece una obligación en donde el empleador responde bajo el criterio de la culpa levísima, véase Corte Suprema, 29 de octubre de 2008, rol N $4855-08$ y Corte Suprema, 8 de agosto de 2000. RDJ, tomo XCVII, Santiago, 2000, $2^{\text {a }}$ parte, sec. 3, p. 152 y ss.; Corte Suprema, 27 de mayo de 1999, $R D J$, tomo XCVI, Santiago, 1999, $2^{\text {a }}$ parte, sec. 3, p. 89 y ss. 
Lo anterior produce, al menos, dos grandes efectos:

- El primer efecto es que el $C C$ establece paralelamente tanto un incumplimiento contractual subjetivo, basado en el juicio de reproche sobre la conducta del deudor, y un incumplimiento contractual objetivo, basado en la no ejecución de lo prometido, donde al deudor no le es permitido acreditar el cumplimiento a través de la prueba de una debida diligencia.

- El segundo efecto, inherente al primero, consiste en que la dualidad "prestación contractual-conducta diligente" como instituciones independiente una de la otra que forman en conjunto el contenido de la obligación contractual, no es la regla general en esta materia, ya que en las obligaciones de dar, de no hacer, y en algunas de hacer, el contenido de la obligación no incluye la "conducta diligente", siendo en dichos casos la prestación por sí sola su contenido, no pudiendo diferenciarse. En este último caso, el hecho generador del incumplimiento contractual del deudor se acredita por la prueba de la inejecución de la prestación prescindiéndose del juicio de valor sobre la conducta del deudor. El referido segundo efecto trae consigo una consecuencia relevante para la historia interpretativa de nuestro $C C$, consistente en que el artículo 1547 y la posibilidad de acreditar el cumplimiento de la obligación contractual sobre la base de la prueba de la diligencia debida a pesar de la no ejecución de la prestación acordada, tiene un campo de aplicación limitado exclusivamente a ciertas obligaciones contractuales de hacer.

A continuación, argumentaremos la razón por la cual el denominado incumplimiento contractual subjetivo basado en el artículo 1547 del $C C$ no puede ser la norma aplicable al incumplimiento de todas las obligaciones de dar, de hacer y de no hacer ${ }^{76}$.

\section{II.- LA RESPONSABILIDAD CONTRACTUAL OBJETIVA en el Código CIVIL Chileno}

En la primera parte de este trabajo constatamos que nuestro $C C$ establece dos mecanismos de configuración del hecho generador del incumplimiento de las obligaciones contractuales. Por un lado, se establece la existencia de un incumplimiento subjetivo y, por el otro, la existencia de uno objetivo.

A continuación, daremos las razones por las cuales no es posible aceptar, en nuestro ordenamiento jurídico, un campo de aplicación general

${ }^{76}$ Véase TAmayo Jaramillo (n. 32), No 318-453, en especial, Nº357-364, quien llega a una conclusión similar pero a través de otra línea argumentativa. 
para el artículo 1547 del $C C$, para, posteriormente, ver los efectos que genera en nuestro sistema civil un incumplimiento contractual objetivo, rechazando el argumento de que hay culpa por parte del deudor por el solo hecho de la inejecución de lo prometido.

\section{Crítica a la idea de que el artículo 1547 debe tener un campo de aplicación general y crítica a la idea de que hay culpa por el solo hecho del incumplimiento de la obligación contractual}

Sobre la base de la ubicación del artículo 1547 del $C C$, la doctrina nacional establece que sin la culpa del deudor no es posible configurar responsabilidad contractual ${ }^{77}$. En igual sentido, parte de la doctrina extranjera ha señalado que la culpa es una condición necesaria en la inejecución de la obligación ${ }^{78}$ siendo el fundamento de la responsabilidad contractual ${ }^{79}$, donde toda inejecución no imputable a una causa ajena constituye culpa ${ }^{80}$ porque, en el fondo, toda obligación contractual exige al deudor una cierta diligencia ${ }^{81}$.

Sin perjuicio de lo anterior, sostendremos que el artículo 1547 del $C C$ no puede ser aplicable a todo incumplimiento de obligaciones contractuales, junto con criticar la idea de que todo incumplimiento constituye 58 culpa.

El $C C$ entiende por presunción el hecho de que de ciertas circunstancias o antecedentes conocidos se puede, lógicamente, deducir la ocurrencia o existencia de otra circunstancia, hecho o antecedente, es decir, se deduce o se concluye algo de un hecho conocido. Las presunciones se enmarcan en el $C C$ como un medio o instrumento probatorio, regulándose dicho medio de prueba en sus artículo 47 y 1712 según si la presunción

${ }_{77}$ Véase (n. 1), (n. 2) y (n. 3).

${ }^{78}$ Christophe RAdÉ, "L'impossible divorce de la faute et de la responsabilité civile", dans Recueil Dalloz, No 38, Paris, 1998, Chronique, No 19, p. 305.

${ }^{79}$ André TunC, "Force majeure et absence de faute en matière contractuelle", dans RTD Civil, Paris, 1945, $\mathrm{N}^{\circ}$ 1, p. 235; No 9, p. 243 et $\mathrm{N}^{\circ}$ 15, p. 248. También, Paul Esmein, "Le fondement de la responsabilité contractuelle", dans RTD Civil, Paris, 1933, p. 690, No 29.

${ }^{80}$ Henri Mazeaud, "Essai de classification des obligations: Obligations contractuelles et extra-contractuelles: Obligations déterminées et obligation générale de prudence et diligence", dans RTD Civil, 1936, N 59, p. 50.

${ }^{81}$ André Tunc, "La distinction des obligations de résultat et des obligations de diligence", dans La Semaine Juridique, I, Paris, 1945, Nº 449 donde sostiene: "qu'au fond, toute obligation contractuelle a pour objet une certaine diligence du débiteur", $\mathrm{N}^{\mathrm{o}} 3$, ya que "la réalisation d'un résultat supposant toujours une diligence", $\mathrm{N}^{\circ} 14$. A pesar de esto, dicho autor reconoce que la obligación de dar es una excepción a dicha regla, op. cit., $\mathrm{N}^{\circ} 3$.; André PlancQueel, "Obligations de moyens, obligations de résultat", dans RTD Civil, Paris, 1972, p. 334 et ss. 
está establecida en la ley o si es deducida por el juez. Las presunciones establecidas en la ley pueden ser presunciones legales o presunciones de derecho, dependiendo de si se permite o no la prueba en contrario. En las legales es posible dicha prueba, en las de derecho no.

Para efecto del presente trabajo nos interesa apuntar que la presunción de culpa establecida en el inciso $3^{\circ}$ del artículo 1547 del $C C$ permite al deudor-demandado acreditar que, a pesar de no haber podido ejecutar la prestación debida, actuó diligentemente y por medio de esa prueba acreditar que sí cumplió con su obligación contractual, desvirtuando la presunción legal de culpa que recae sobre él. Por ejemplo, en la obligación de hacer, consistente en reparar un motor, el deudor no será responsable de los daños que dicha cosa sufra si prueba o acredita que en su reparación se comportó de manera diligente a pesar de no haber logrado ejecutar la prestación debida de la manera deseada por el acreedor ${ }^{82}$.

Por otra parte, vimos que el incumplimiento de las obligaciones de dar, de no hacer o en ciertas de hacer, éste se configura por la sola circunstancia de no haberse dado, de haberse ejecutado lo que no había que hacer, o de no haberse hecho lo que se debió hacer ${ }^{83}$. Sobre la base de esto, ċes posible que quién deba una suma de dinero pueda acreditar el

${ }^{82}$ Corte Suprema, casación en la forma y fondo de 29 de agosto de 1994, en autos caratulados "Aetna Chile S.A. con Distribuidora Cummins Diesel S.A.”. Número Microjuris: MJJ1445/RDJ1445. Los hechos consistieron en que tras la reparación, colocación e instalación de un cigüeñal en un motor de una nave pesquera, igualmente el motor sufrió fallas con posterioridad. Teniendo dicho hecho como antecedente, la Excma. Corte Suprema resolvió que a pesar de la acreditación de dichas fallas, "la reparación se llevó a cabo convenientemente" (considerando $19^{\circ}$ ), y ello significa, según el considerando $10^{\circ}$, que "se empleó en ello la debida diligencia de modo que el desperfecto ya no le es imputable a quien tuvo a su cargo el cumplimiento del deber que le imponía el contrato". En sentido similar, pero con un voto de minoría, véase Corte Suprema, fallo casación en el fondo y forma de 10 de diciembre de 2008, rol 1771-07, No Microjuris MJJ19078. Dicho fallo resolvió que tras la reparación "formal" del motor que con el uso volvió ha colapsar, el deudor no es responsable de dicho colapso porque acreditó su debida diligencia en la ejecución del arreglo. Asimismo, se reconoce, como se desprende del considerando $23^{\circ}$ que "le corresponde al acreedor la prueba de la existencia de la obligación, siendo al deudor, en este caso la demandada, probar su cumplimiento, o en subsidio, su diligencia o finalmente, el caso fortuito, si se consideran de manera literal las normas de los artículos 1547 y 1698 del Código Civil". Es decir, si el deudor no logra acreditar el cumplimiento puede -subsidiariamente- acreditar que se comportó de manera diligente, y sobre la base de dicha diligencia, no ser responsable de los daños sufridos por el acreedor porque la obligación contractual se encuentra cumplida. Sobre esta última sentencia véanse los diferentes comentarios de Álvaro Vidal Olivares, Carlos Pizarro Wilson y Mauricio Tapia Rodríguez, en Facultad de Derecho, Universidad de Concepción, Estudios de Derecho Civil v, Santiago, Abeledo Perrot, 2010, pp. 569-585, 587-593 y 595-602, respectivamente.

${ }^{83}$ Véanse las letras a, b, d, e, f y g del punto 2 de la primera parte de este trabajo. 
cumplimiento de su obligación alegando que se comportó diligentemente a pesar de no haber pagado o transferido la suma de dinero debida? o ¿̇es posible que quién se obligó a no talar un bosque alegue que se comportó diligentemente a pesar de haberlo talado? Las respuestas a dichas preguntas son negativas ${ }^{84}$. Si el deudor no cumplió con su obligación de dar, de no hacer, o ciertas obligaciones de hacer, incumple sólo por no haber dado, por haber hecho lo que no debió hacer o para ciertos casos, por no hacer lo que se obligó a haber.

Dado lo anterior, ¿cabe presumir la culpa contractual del deudor en los términos del inciso $3^{\circ}$ del artículo 1547 del $C C$ ? Claramente no es posible, porque el deudor sólo puede probar el cumplimiento de dichas obligaciones acreditando la ejecución misma y no a través de la prueba de su debida diligencia, desvirtuando así la presunción legal de culpa ${ }^{85}$. Pretender enmarcar la inejecución de dichas obligaciones bajo la idea de que hay culpa por el solo hecho del incumplimiento significaría presumir de pleno derecho la culpa contractual, lo cual no es aceptable. Aceptarlo, llevaría a que la presunción establecida en el inciso $3^{\circ}$ el artículo 1547 del $C C$ tendría un doble carácter: legal para ciertas obligaciones de hacer y, de derecho para el resto de las obligaciones contractuales. Dicha dualidad, cuya única finalidad es justificar la corriente doctrinaria que sostiene que el incumplimiento contractual se basa en la culpa del deudor, es incompatible con la técnica jurídica establecida para las presunciones. Una presunción no puede ser a la vez legal y a la vez de derecho.

Presumir de pleno derecho la culpa contractual en el incumplimiento de las obligaciones de dar, de no hacer y en ciertas de hacer, es atentar contra el propio sistema establecido en los incisos $1^{\circ}$ y $3^{\circ}$ del artículo 1547 del $C C$, incisos que diferencian, por un lado, la prestación contractual y, por el otro, la culpa o reprochabilidad de la conducta del deudor. Si se llegase a aceptar que la culpa es presumida de pleno derecho, ello generaría, al menos, dos efectos indeseables. El primero es que se tratarían como equivalentes o sinónimos las nociones de 'culpa' y de 'inejecución de la prestación debida', generando el efecto de que no tendría sentido hablar de culpa contractual, ya que estaría comprendida, presumida de pleno derecho, dentro de la inejecución de la prestación misma, bastando únicamente hacer mención a esta última. El segundo efecto no deseado, consistiría en desconocer que ambos términos son instituciones diferen-

${ }^{84}$ Véanse las letras a, b, d, e, f y g del punto 2 de la primera parte de este trabajo.

${ }^{85}$ Véase la Primera conclusión del presente trabajo. A pesar de lo anterior, cabe tener presente que el deudor siempre podrá eximirse de responsabilidad (que no es lo mismo que acreditar el cumplimiento de la obligación contractual) destruyendo el nexo causal a través de la prueba de una causa ajena a su persona, como lo es el caso fortuito, la fuerza mayor, el hecho de un tercero o un hecho del acreedor. 
tes e independientes uno del otro. Igualarlos significaría desconocer la mecánica misma de los incisos $1^{\circ}$ y $3^{\circ}$ del artículo 1547 del $C C$, los que, paradójicamente, son la fuente misma de dicha línea argumentativa.

Pretender justificar que hay culpa en el incumplimiento de las obligaciones de dar, de no hacer y en ciertas de hacer sin permitirle al deudor acreditar que cumplió con su obligación contractual probando su debida diligencia, a pesar de no haber ejecutado la prestación, significa transformar la presunción legal de culpa regulada en el inciso $3^{\circ}$ del artículo 1547 , en una presunción de pleno derecho, lo cual no es aceptable desde la técnica jurídica establecida en el mismo $C C$.

\section{Efectos de una responsabilidad contractual objetiva}

Hemos podido constatar que la culpa contractual no es el fundamento de todo incumplimiento de contrato, únicamente es un elemento necesario para configurar el hecho generador del incumplimiento de ciertas obligaciones de hacer. Argumentar que la culpa es el fundamento de todo incumplimiento contractual es desconocer y contradecir el sentido mismo de la presunción legal de culpa establecida en el inciso $3^{\circ}$ del artículo 1547 del $C C$. El incumplimiento de una obligación de dar, de no hacer y en ciertas de hacer se configura por la sola acreditación de la inejecución misma de la obligación, de manera objetiva, sin importar la conducta desplegada por el deudor. Este tipo de obligaciones ha sido denominada por la doctrina como las de resultado, las que se diferencian de las de medios cuyo incumplimiento se configura subjetivamente, es decir, tras constatar que la conducta del deudor fue reprochable, dando origen a una responsabilidad contractual subjetiva.

Los efectos de una responsabilidad contractual objetiva, en relación con la responsabilidad contractual subjetiva son los siguientes:

- Primero, el deudor de una obligación de resultado, es decir de una obligación de dar, de no hacer y en ciertas de hacer, no podrá acreditar el cumplimiento por medio de la prueba de la debida diligencia sino que únicamente por medio de la prueba de la inejecución de la obligación misma. Ello es la diferencia principal con las obligaciones de medios, que dan origen a una responsabilidad contractual subjetiva, en donde el deudor tras no haber podido realizar o ejecutar la prestación prometida siempre podrá acredita el cumplimiento demostrando que actuó resueltamente, con la diligencia exigida.

- Segundo, el deudor de una obligación de resultado tiene dos alternativas para no ser responsable de los daños sufridos por el acreedor: probar el cumplimiento de la obligación misma o probar 
una eximente de responsabilidad que destruya el nexo causal, como un caso fortuito, un hecho de un tercero, etc. En cambio, el deudor de una obligación de medios tiene tres alternativas para no ser responsable de los daños sufridos por el acreedor: probar el cumplimiento de la prestación contractual, probar que actuó diligente mente a pesar de no haber podido ejecutar la prestación, o probar una eximente de responsabilidad. Dado lo anterior, el deudor, independientemente de si la obligación es de resultado o de medios, siempre podrá eximirse de responsabilidad, acreditando un evento o hecho ajeno a su voluntad que impida la configuración del nexo causal entre el hecho, acto u omisión en la ejecución de la obligación y el daño sufrido por el acreedor ${ }^{86}$.

- Tercero, como hemos podido constatar el fundamento de la responsabilidad contractual no es la reprochabilidad a la conducta del deudor, sino que es, simplemente, el incumplimiento mismo ${ }^{87}$. Que sea el incumplimiento contractual y no la conducta del deudor el fundamento de la responsabilidad contractual no afecta la condena a indemnizar los perjuicios ${ }^{88}$, como gran parte de la

${ }^{86}$ Esto último hace insostenible la crítica argumentativa que sostiene, para rechazar la noción de obligación de resultado, que el deudor no puede ser responsable a todo evento de los daños que sufra el acreedor por la no realización de la obligación. Dicha doctrina defiende la idea de que sin culpa no es posible establecer responsabilidad contractual al asimilar, para rechazar la existencia de una responsabilidad objetiva configurada por el incumplimiento de una obligación de resultado, el hecho generador del incumplimiento con el nexo causal y sobre la base de dicha asimilación argumentar que: "en el fondo, no existen obligaciones de resultado, entendiendo como tales aquellas que deben cumplirse siempre, en todo evento y en cualquier caso", Pablo Rodríguez Grez, La obligación como deber de conducta típica (La teoría de la imprevisión en Chile), Santiago, Ediciones Facultad de Derecho Universidad de Chile, Editorial Salesianos, 1992, p. 103; para continuar manifestando que el deudor "no puede, sin embargo, hacerse responsable del dolo o culpa grave del acreedor en el evento de que este obstruya el cumplimiento de la obligación", (n. 1), No 381 letra e., p. 210.

Nosotros no compartimos el señalado argumento para ir en contra de la denominada obligación de resultado, pues el efecto que produce la culpa grave o dolo del acreedor es la configuración de un eximente de responsabilidad que destruye el nexo causal entre el daño sufrido por el acreedor y el hecho, acto u omisión del deudor. Argumentar que todas las obligaciones son de medios porque es necesario la culpa del deudor, en razón de que éste no puede ser responsable del dolo del acreedor, es fundir en uno dos de los elementos de la responsabilidad contractual, a saber, fundir el hecho generador con el nexo causal, lo cual no es aceptable. Respecto de los efectos de la culpa del acreedor véase Carlos Ducci Claro, "La culpa del acreedor en la responsabilidad contractual", en RDJ, tomo LXXXI, Santiago, $1984,1^{\text {a }}$ parte, pp. 1-8.

${ }^{87}$ Peñailillo Arévalo (n. 4), p. 343, afirma: "el fundamento de la responsabilidad es el incumplimiento contractual, no la culpa”. Asimismo, TAllon (n. 20), p. 437.

${ }^{88}$ Véanse las sentencias descritas en las letras a, b y g del número 2 de la primera parte de este trabajo, donde se puede apreciar que la condena al pago de los perjuicios se 
doctrina ha pretendido señalar. El contrato es por esencia un acto de previsión y es sobre la base de dicha característica que en el evento del incumplimiento de la obligación sólo se deban los perjuicios que se hayan podido prever al momento de celebrarse el contrato. Dicho criterio de avaluación de los perjuicios tiene una excepción que se aplica cuando la inejecución de la obligación por parte del deudor fue con intención de dañar al acreedor (lo cual no fue previsto), es decir, una inejecución dolosa. En dicho evento los perjuicios que se deben pagar ya no son los previstos al momento de la celebración del contrato, sino que son todos los que son una consecuencia inmediata o directa de no haberse cumplido la obligación contractual ${ }^{89}$, lo cual amplía los daños a indemnizar. Así lo establece el artículo 1558 del $C C$, artículo cuyo criterio para establecer el monto de los perjuicios es sobre la base de si el deudor actuó o no con intensión de dañar, con dolo, prescindiendo para ello de la noción de culpa ${ }^{90}$.

- El último efecto que produce la responsabilidad contractual objetiva es la inaplicabilidad de la regla, para el caso de las obligaciones de resultados, que establece que la culpa grave en materia civil equivale al dolo. Para demandar los perjuicios imprevistos causados por el incumplimiento de una obligación de resultado, el acreedor

efectuó prescindiendo de la constatación de la culpa del deudor. Véase también a Daniel Peñailillo Arévalo, "La reforma del Código Civil francés en el derecho de obligaciones y el Código Civil Chileno", en Revista Chilena de Derecho Privado, No 8, Santiago, julio 2007, p. 242, quien señala: "no hay regla que disponga si en ausencia de culpa el deudor debe o no responder, solo hay una según la cual la prueba de la diligencia o cuidado incumbe al que ha debido emplearla".

${ }^{89}$ Ésta es una de las diferencias entre la responsabilidad contractual y la extracontractual. En la primera los perjuicios se determinan sobre la base de la previsibilidad, con la excepción del dolo del deudor; en la segunda, el criterio de evaluación de los perjuicios no es la previsibilidad sino el dejar a la víctima en iguales condiciones a las que se encontraba con anterioridad a sufrir el ilícito extracontractual, es decir, a indemnizar todos los daños sufridos. En la doctrina extranjera, véase Luis Díez-Picazo, quien sostiene: "El deudor de buena fe sólo responde en los límites del daño previsible en el momento de contratar y sólo el deudor doloso responde de todos los que conocidamente deriven de la falta de cumplimiento de la obligación”, en Luis DíEz-Picazo, Derecho de daños, Madrid, Civitas, 1999, p. 247.

${ }^{90}$ Peñailillo Arévalo (n. 4), pp. 337-339. Véase también Carlos Pizarro Wilson, "La culpa como elemento constitutivo del incumplimiento en las obligaciones de medio o de diligencia", en Revista de Derecho Pontificia Universidad Católica de Valparaíso, tomo XXXI, Valparaíso, 2008, quien a pesar de estar de acuerdo con la clasificación obligaciones de medio-obligaciones de resultado propone darle una interpretación en clave objetiva al artículo 1557 del $C C$. y así permitir la procedencia de la indemnización de perjuicios sin aplicar la teoría de la prestación de culpas. p. 263. 
deberá probar el dolo del deudor, su intención positiva, con todas las dificultades procesales que ello trae consigo en lugar de probar una negligencia grave.

\section{CONCLUSIÓN}

¿Cómo es posible conjugar las sentencias de la Excma. Corte Suprema en materia de responsabilidad contractual que, por un lado, permiten al deudor que no ejecutó la prestación acreditar el cumplimiento de la obligación por medio de la prueba de su debida diligencia y, por el otro, sentencias que por el solo hecho de acreditar que no se ejecutó lo pactado se configura la inejecución de la obligación contractual sin importar la diligencia empleada por el deudor? La única respuesta satisfactoria a dicha dualidad de exigencias es que nuestro $C C$ establece dos sistemas o mecanismos de configuración del hecho generador del incumplimiento de la obligación. Uno objetivo, que prescinde de la valoración de la conducta desplegada por el deudor, y otro subjetivo, que necesita valorar negativamente su conducta para constatar la culpa.

Dicha dualidad produce, al menos, dos grandes cambios al cómo se han estudiado hasta hoy los efectos de la inejecución de la obligación contractual. El primero de ellos es que los incisos $1^{\circ}$ y $3^{\circ}$ del artículo 1547 del $C C$ carecen de aplicación general, teniendo injerencia únicamente para el caso de ciertas inejecuciones de obligaciones de hacer, no siendo aplicable para el incumplimiento de las obligaciones de dar, de no hacer y ciertas de hacer. El segundo efecto es que la definición de incumplimiento contractual no puede tener dentro de sus elementos la reprochabilidad del deudor, ya que, como pudimos apreciar a lo largo de este trabajo, ella sólo es requisito en el evento de inejecución de ciertas obligaciones de hacer. Es por ello que el contenido de la obligación contractual varía dependiendo de lo que se tenga que ejecutar. En algunos casos, como lo ha señalado casi uniformemente la doctrina (pero de manera equivocada otorgándole un campo de aplicación general), el contenido de la obligación contractual es la conducta diligente del deudor en la ejecución de la prestación prometida, y en otros, el contenido es la prestación misma sin importar la conducta desplegada por el deudor, donde los términos prestación-obligación no pueden diferenciarse uno del otro. Ello trae consigo el siguiente efecto: sólo en el primer caso le es posible al deudor acreditar o probar el cumplimiento por medio de la prueba de la debida diligencia en el caso de inejecución de la prestación debida. En otras palabras, la prueba de la debida diligencia por parte del deudor sólo se permite y produce sus efectos en la inejecución de la prestación de ciertas obligaciones de hacer. 
En razón de lo anterior, los requisitos para establecer la responsabilidad contractual del deudor varían en uno y en otro caso, dependiendo de si lo que se incumplió fue una obligación de resultado (de dar, de no hacer y ciertas de hacer) o una obligación de medios (cierta de hacer), siendo el elemento que los diferencia la necesidad o no de realizar un juicio de reproche a la conducta del deudor.

Esto último permite redefinir el criterio de identificación de la denominada obligación de resultado, ya no centrándose en la satisfacción que el demandado promete al acreedor sino que determinando si le es posible o no al deudor probar el cumplimiento de su obligación contractual acreditando su debida diligencia. Si le es permitido, la obligación es de medios, donde la culpa es el fundamento de la responsabilidad contractual, y si no le es permitido, la obligación es de resultado siendo su fundamento el solo incumplimiento de lo prometido o pactado.

Sin perjuicio de todo lo anterior, se debe tener la siguiente aprehensión: cuando el incumplimiento de la obligación contractual sea producto del dolo del deudor, la responsabilidad contractual siempre será subjetiva.

\section{BiBLIOGRAFÍA}

Abeliuk Manasevich, René, Las obligaciones, $5^{\text {a }}$ ed., Santiago, Editorial Jurídica de Chile, 2008, tomo II.

Alessandri, Arturo, De las obligaciones, Santiago, Nascimento, 1941.

Alessandri R, Arturo, Manuel Somarriva U. y Antonio Vodanovic H., Tratado de las obligaciones. Del cumplimiento e incumplimiento de las obligaciones, $2^{\mathrm{a}}$ ed., Santiago, Editorial Jurídica de Chile, 2004.

Facultad de Derecho, Universidad de Concepción, Estudios de Derecho Civil v, Santiago, Abeledo Perrot, 2010.

BaCACHE-Gibeil, Mireille, Les obligations. La responsabilité civile extracontractuelle, sous la direction de Christian Larroumet, Paris, Economica, tome v, 2007.

BARAONA GonZÁlez, Jorge, "Responsabilidad contractual y factores de imputabilidad de daños: apuntes para una relectura en clave objetiva", en Revista Chilena de Derecho, vol. 24, No 1, Santiago, 1997.

Barros Errázuriz, Alfredo, Curso de Derecho Civil, segundo año, $4^{\mathrm{a}}$ ed., Santiago, Nascimento, 1932.

BARros Bourie, Enrique, "La diferencia entre 'estar obligado' y 'ser responsable' en el derecho de los contratos", en Hernán Corral TalCiani y María Sara Rodríguez Pinto (coords.), Estudios de Derecho Civil II, Santiago, LexisNexis, 2007.

Barros Bourie, Enrique, Tratado de responsabilidad civil extracontractual, Santiago, Editorial Jurídica de Chile, 2006.

Carbonnier, Jean, Droit Civil, $1^{\text {ème }}$ ed., "Quadrige" Paris, P.U.F., vol. II, 2004. 
CoËFfard, Paul, Garantie des vices cachés et "responsabilité contractuelle de droit commun”, préface de Philipe Remy, Paris, LGDJ, Université de Poitiers, 2005.

Corral Talciani, Hernán, "Responsabilidad civil en la construcción de viviendas. Reflexiones sobre los regímenes legales aplicables a los daños provocados por el terremoto del 27 de febrero de 2010", en www.microjuris.cl, $N^{\circ}$ identificador MJCH_MJD387.

Claro Solar, Luis, Explicaciones de Derecho Civil chileno y Comparado, Santiago, Nacimento, 1936 y 1937, tomos x y xI, respectivamente.

Court Murasso Eduardo, "Algunas consideraciones en torno a la responsabilidad civil por vicios de la construcción en las legislaciones de España y de Chile”, en Fundación Fernando Fueyo Laneri, Estudios de Derecho Privado. Homenaje a Gonzalo Figueroa Yañez, Santiago, Editorial Jurídica de Chile, 2008.

De la Maza Gazmuri, Iñigo, "A propósito del artículo 1861”, en Facultad DE Derecho, Universidad de Concepción, Estudios de Derecho Civil v, Santiago, Abeledo Perrot, 2010.

De la Maza Rivadeneira, Lorenzo, "Responsabilidad contractual", en Revista Chilena de Derecho, vol. 16, Santiago, 1989.

Díez-Picazo, Luis, Derecho de daños, Madrid, Civitas. 1999.

Demogue, René, Traité des Obligations en général, Paris, Rousseau, tome v, 1925.

Demogue, René, Traité des Obligations en général, Paris, Rousseau, tome IV, 1931.

Domínguez Águila, Ramón, "La culpa en el derecho civil chileno. Aspectos Generales", en Revista Anales Derecho UC. Temas de Responsabilidad Civil, No 3, Santiago, 2008.

Ducci Claro, Carlos, "La culpa del acreedor en la responsabilidad contractual”, en $R D J$, tomo LxxxI, Santiago, 1984, $1^{\mathrm{a}}$ parte.

Esmein, Paul, "Le fondement de la responsabilité contractuelle", dans RTD Civil, Paris, 1933.

FABres, José Clemente, Instituciones de derecho civil chileno, $2^{\mathrm{a}}$ ed., Santiago, Ercilla, tomo II, 1902.

Figueroa Velasco, Patricio y Juan Eduardo Figueroa Valdés, Urbanismo y construcción, Santiago, LexisNexis, 2006.

Fueyo LANERI, Fernando, Cumplimiento e incumplimiento de las obligaciones, $3^{\mathrm{a}}$ ed., Santiago, Editorial Jurídica de Chile, 2004.

García GonzÁlez, Alejandro, Responsabilidad civil contractual-obligaciones de medios y de resultado, Santiago, LexisNexis, 2002.

Gatica Pacheco, Sergio, Aspecto de la indemnización de perjuicios por incumplimiento del contrato, Santiago, Editorial Jurídica de Chile, 1959.

GuZmán Brito, Alejandro, "La responsabilidad objetiva por custodia en el derecho romano y en el derecho moderno, con una referencia especial a la regla periculum est emptoris", en Revista Chilena de Derecho, Santiago, vol. 24, 1997. 
Illanes Ríos, Claudio, "El contrato de construcción a suma alzada", en Publicaciones del Colegio de Abogados de Chile, Santiago, Colegio de Abogados de Chile A.G., junio de 1996.

Lambert- FaIvre, Yvonne, "L'éthique de la responsabilité", dans RTD Civil, Paris, 1998.

LARraín Ríos, Hernán, Teoría general de las obligaciones, Santiago, LexisNexis, 2002.

Larroumet, Christian, Les Obligations. Le Contrat, 6 ${ }^{\mathrm{ème}}$ ed, Paris, Economica, 2007, tome III, vol. 2.

LE BRun, Dennis, "Essai sur la prestation des fautes, ou l'on examine combien les lois romaines en distinguent d'espèces”, publicado en Paris por Saugrain en 1764 y anexado en Robert J. Pohier, Euvres de Pothier, Traité des obligations $3^{\text {ème }}$ ed., par M. Jean-Joseph Bugnet, Paris, Imprimerie L. Baudoin, 1890, tome 2.

Martínez Cárdenas, Betty Mercedes, "La faute y la culpa", en Fabricio Mantilla Esponoza y Carlos Pizarro Wilson (coords.) Estudios de Derecho Privado en homenaje a Christian Larroumet, Santiago-Bogotá, Ediciones de la Fundación Fernando Fueyo, Universidad Diego Portales-Universidad del Rosario, 2008.

MAzEAud, Henri, "Essai de classification des obligations: Obligations contractuelles et extra-contractuelles: 'obligations déterminées' et 'obligations générale de prudence et diligence", dans RTD Civil, Paris, 1936.

Mazeaud, Henri et Léon et André Tunc, Tratado teórico y práctico de la responsabilidad civil delictual y contractual, Buenos Aires, Ediciones Jurídica EuropaAmérica, traducido de la $5^{\mathrm{a}}$ edición por Luis Alcalá-Zamora y Castillo, tomo 1, vol. 1, 1961.

Peñailillo Arévalo, Daniel, "Responsabilidad contractual objetiva", en Carlos PIZarro (coord.), Estudios de Derecho Civil IV, Santiago, Legal Publishing, 2009.

Peñailillo Arévalo, Daniel, "La reforma del Código Civil francés en el derecho de obligaciones y el Código Civil chileno", en Revista Chilena de Derecho Privado, No 8, Santiago, julio 2007.

Pizarro Wilson, Carlos, "La culpa como elemento constitutivo del incumplimiento en las obligaciones de medio o de diligencia", en Revista de Derecho Pontificia Univrsidad Católica de Valparaíso, tomo xxxi, Valparaíso, 2008.

Pizarro Wilson, Carlos, "La fuerza mayor como defensa del deudor. A propósito de la restricción de suministro de gas a Chile", en Revista Chilena de Derecho Administrativo Económico, $\mathrm{N}^{\circ}$ 14, Santiago, 2008.

PlancQueel, André, “Obligations de moyens, obligations de résultat”, dans RTD Civil, Paris, 1972.

Pothier, Robert-Joseph, Euvres de Pothier, Traité des obligations, $3^{\text {ème }}$ ed., par $M$. Jean-Joseph Bugnet, Paris, Imprimerie L. Baudoin, 1890, tome II.

Pothier, Robert Joseph, Euvres de Pothier, Traité de contrat de vente, par M. JeanJoseph Bugnet, Paris, Imprimerie de Cosse, 1847, tome III.

Pothier, Robert-Joseph, Euvres de Pothier, Traités de Contrat Louage, du Contrat de bail à rente, du Contrat de société, des Cheptels des Contrats des louages maritimes, 
$d u$ Contrat de change, par M. Jean-Joseph Bugnet, Paris, Imprimerie de Cosse, 1847 , tome IV.

RADÉ, Christophe, "L'impossible divorce de la faute et de la responsabilité civile", dans Recueil Dalloz, No 38, Paris, 1998, Chronique.

RÉmy, Philippe, "La responsabilité contractuelle: histoire d'un faux concept", dans RTD Civil, Paris, 1997.

RIPERT, Georges, La régle morale dans les obligations civiles, 2 ${ }^{\text {ème }}$, Paris, LGDJ, 1927.

Rodríguez Grez, Pablo, La obligación como deber de conducta típica (La teoría de la imprevisión en Chile), Santiago, Ediciones Facultad de Derecho Universidad de Chile, Editorial Salesianos, 1992.

Rodríguez Grez, Pablo, Responsabilidad contractual, Santiago, Editorial Jurídica de Chile, 2003.

Rodríguez Pinto, María Sara, "Incumplimiento y exoneración de responsabilidad en los contratos de servicios. Los lineamientos de la responsabilidad estricta del proveedor", en Alejandro GuZmán Brito, Estudios de Derecho Civil III, Santiago, LegalPublishing, 2008.

Rosso ElorRiaga, Gian Franco, "El buen padre de familia como criterio de apreciación de la culpa y su aplicación a la responsabilidad civil cuasidelictual", en VV.AA, Derecho de daños, Santiago, Lexinexis, 2002.

TAmayo Jaramillo, Javier, La culpa contractual, Bogota, Temis, 1990.

Tamayo Jaramillo, Javier, Tratado de responsabilidad civil, $2^{\mathrm{a}}$ reimpresión de la $2^{\mathrm{a}}$ ed., Bogotá, Legis, 2008.

TAllon, Denis, "Pourquoi parler de faute contractuelle?", dans Jean BeAUChard et Pierre Couvrat, Droit Civil, procédure, linguistique juridique. Écrits en hommage à Gerard Cornu, Paris, PUF, 1994.

Toullier, Charles Bonaventure Marie, Le droit civil français suivant l'ordre du Code, $4^{\text {ème }}$ ed., Paris, Ed. Warée, 1824, tome VI.

Tunc, André, "La distinction des obligations de résultat et des obligations de diligence", dans La Semaine Juridique, I, Paris, 1945.

Tunc, André, "Force majeure et absence de faute en matière contractuelle", dans RTD Civil, Paris, 1945.

Urrejola Santa María, Sergio, La responsabilidad profesional de los agentes de la construcción, Santiago, LexisNexis, 2004.

Vial del Río, Víctor, Manual del Derecho de las Obligaciones en el Código Civil chileno, Santiago, Editorial Biblioteca Americana, 2003.

Vidal Olivares, Álvaro, "Cumplimiento e incumplimiento contractual en el Código Civil. Una perspectiva más realista”, en Revista Chilena de Derecho, 2007, vol. $34 \mathrm{~N}^{\circ} 1$, p 41 a 59.

VIDAL OlIVAREs, Álvaro, "Incumplimiento y atribución de responsabilidad en las obligaciones de medio y resultado (a propósito de una sentencia de la Corte 
Diciembre 2011 El HeCHO GENERADOR DEL INCUMPLIMIENTO CONTRACTUAL y El ARTículo 1547 DEL CóDIGo CIVIL

Suprema $\mathrm{N}^{\circ}$ ingreso 1.771-2008), en Facultad de Derecho, Universidad de Concepción, Estudios de Derecho Civil v, Santiago, AbeledoPerrot, 2010.

Viney, Geneviève, Traité de Droit Civil, Introduction à la Responsabilité, $2^{\text {éme }}$ ed., Paris, LGDJ, 1995. 